\title{
Functional diversity of ectomycorrhizal fungal communities is reduced by trace element contamination
}

López-garcía, Álvaro; Gil-Martínez, Marta; Navarro-fernández, Carmen M.; Kjøller, Rasmus; Azcón-aguilar, Concepción; Domínguez, María T.; Marañón, Teodoro

\section{Published in:}

Soil Biology and Biochemistry

DOI:

10.1016/j.soilbio.2018.03.021

Publication date:

2018

Document version

Peer reviewed version

Citation for published version (APA):

López-garcía, Á., Gil-Martínez, M., Navarro-fernández, C. M., Kjøller, R., Azcón-aguilar, C., Domínguez, M. T., \& Marañón, T. (2018). Functional diversity of ectomycorrhizal fungal communities is reduced by trace element contamination. Soil Biology and Biochemistry, 121, 202-211. https://doi.org/10.1016/j.soilbio.2018.03.021 
1 Title. Functional diversity of ectomycorrhizal fungal communities is reduced by trace element

2 contamination

3 Authors. Álvaro López-García ${ }^{1,2 *}$, Marta Gil-Martínez ${ }^{1 *}$, Carmen M. Navarro-Fernández ${ }^{1}$,

4 Rasmus Kjøller ${ }^{2}$, Concepción Azcón-Aguilar ${ }^{3}$, María T. Domínguez ${ }^{1,4}$, Teodoro Marañón ${ }^{1}$

$5 *$ These authors contributed equally to the study.

6 Addresses:

$7 \quad{ }^{1}$ Dept. Protection of the Soil, Plant and Water System, Instituto de Recursos Naturales y

8 Agrobiología de Sevilla, CSIC, Avda. Reina Mercedes 10, 41012 Sevilla, Spain

$9{ }^{2}$ Dept. Biology, University of Copenhagen, Universitetsparken 15, 2100 Copenhagen $\emptyset$,

10 Denmark

$11{ }^{3}$ Dept. Soil Microbiology and Symbiotic Systems, Estación Experimental del Zaidín, CSIC,

12 Profesor Albareda 1, 18008 Granada, Spain

$13{ }^{4}$ Dept. Crystallography, Mineralogy and Agricultural Chemistry, University of Seville, Prof.

14 García González s/n, 41012, Sevilla, Spain

15 Corresponding author:

16 Álvaro López-García

17 Tfno: +4529869444

18 E-mail: alvaro.lopez.garcia@bio.ku.dk

19 Address: Dept. Biology, University of Copenhagen, Universitetsparken 15, 2100 Copenhagen $\varnothing$,

20 Denmark

21

22 (C) 2018. This manuscript version is made available under the CC-BY-NC-ND 4.0

23 license http://creativecommons.org/licenses/by-nc-nd/4.0/ 


\section{Abstract}

25 Trait-based approaches are useful tools to explain ecological assembly rules and ecosystem

26 functioning. However, their use for soil microbiota has not been explored in depth yet. We

27 explored trait-based functional changes of ectomycorrhizal (ECM) fungal communities

28 associated with holm oak (Quercus ilex subsp. ballota) in a trace element contaminated area.

29 We found a variation in ECM fungal species composition determined by soil $\mathrm{C}, \mathrm{Ca}$ and trace

30 elements; however, taxonomic diversity was not dependant on contamination level. Mean trait

31 values of ECM fungal communities showed less rhizomorph and emanating hyphae production

32 when increasing contamination, and the community converged towards species developing

33 rhizomorphs less frequently. We suggest that trace elements in soils acted as the main

34 environmental filter of trait diversity of ECM fungal communities. The effect of soil nutrients,

35 i.e. soil $\mathrm{C}$, affected the community mean trait values of emanating hyphae but did not cause a

36 convergence in its distribution.

37 In summary, we found a reduction in the functional diversity of ECM fungal communities due to trace element contamination with potential to affect ecosystem functioning. This finding supports

39 the potential of trait-based approaches to assess changes in the functional diversity of soil

40 microbial communities.

41

\section{$42 \quad$ Key words}

43 Community assembly, Ectomycorrhizal fungi, Quercus ilex subsp. ballota (holm oak), Trace 44 element contamination, Traits 


\section{Introduction}

46 Trait-based approaches are excellent tools to disentangle community assembly rules and to link

47 community composition, environmental changes and ecosystem functioning (Díaz \& Cabido,

48 2001; Garnier et al., 2016; Lavorel et al., 2013). The basic principle of trait-based approaches

49 relies on the use of functional traits of organisms, instead of mere species abundance counts, to

50 describe emergent properties of ecosystems (Cadotte et al., 2011). Environmental constraints are

51 known to affect the taxonomic diversity of communities by filtering the species according to

52 their traits -i.e. response traits-, promoting the convergence of species with similar traits, in a

53 process known as environmental filtering (Götzenberg et al., 2012). On the other hand,

54 functional traits that have the potential to change ecosystem functioning are considered effect

55 traits. The degree to which response and effect traits are interrelated determines the possible

56 consequences of environmental filtering (Lavorel and Garnier, 2002).

57

58 In plant ecology, the links between plant traits and ecosystem functioning have been widely

59 explored during recent decades (Díaz et al., 2007). Most studies have been focused on

60 aboveground traits (Bardgett et al., 2014; Laliberté, 2016) and only more recently the "hidden"

61 belowground plant functional diversity has started to be addressed (e.g. Bu et al., 2016; de la

62 Riva et al., 2017; Gould et al., 2016). Indeed, the few studies addressing the belowground

63 compartment of plant communities has, ranging from the level of organisms to that of

64 ecosystems, highlighted the methodological potential for explaining ecosystem functioning (e.g.

65 López-García et al., 2014; Mulder et al., 2005; Pelosi et al., 2014; Santorufo et al., 2015).

66

Despite the growing interest, trait-based studies of soil organisms faces important challenges 
67 especially due to the difficulties associated to the direct trait measurements of individual

68 organisms, especially in the case of microbes (see Crowther et al., 2014).

Ectomycorrhizal (ECM) fungi are important components of terrestrial ecosystems: they are

71 symbiotic nutrient suppliers of trees dominating in wide areas of the globe (van der Heijden et

72 al., 2015). Their impact in ecosystems is not only limited to nutrient (mainly N) and water uptake

73 from the soil, but they also participate in aspects of $\mathrm{C}$ cycling such as $\mathrm{C}$ sequestration

74 (Clemmensen et al., 2013) and organic matter degradation (Tunlid et al., 2017). It has been

75 suggested that their implications for ecosystem processes can be mediated by specific fungal

76 traits which, in turn, are affected by environmental changes (Koide et al., 2014). In particular, the

77 way in which ECM fungal species invest in morphological structures determines the hyphal

78 exploratory capacity. Agerer $(2001 ; 2006)$ distinguished four broad categories of exploration

79 types: contact, short, medium and long distance, as a function of the morphology and

80 development of emanating hyphae and rhizomorphs, i.e. specialised hyphal cords for long

81 distance transport of water and nutrients, in the soil. The relative abundance of species with

82 different exploration types is determined by the nutrient status of soils (Hobbie and Agerer,

83 2010; Moeller et al., 2014; Suz et al., 2014). Indeed, fungi exhibiting different exploration types

84 usually harbour different enzyme activities (Tedersoo et al., 2012). Additionally, it has been

85 suggested that ECM exploration type drives long term $\mathrm{C}$ sequestration due to differences in

86 biomass production and turnover among them (Clemmensen et al., 2015; Koide et al., 2014).

87 Another relevant trait with implications for ecosystem processes is the melanin content in cell

88 walls, which is considered a protective trait against multiple abiotic stressors (Treseder and

89 Lennon, 2015) such as enzymatic degradation (Rosas and Casadevall, 2000), salinity (Kogej et 
al., 2006), water stress (Fernandez and Koide, 2013) and even ionising radiation (Cordero,

91

92 2017). Melanin content is inversely related to the decomposition rates of fungal necromass due to its recalcitrant nature (Fernandez and Koide, 2014), and thus it has the potential to influence C storage in soil, acting as an effect trait (Clemmensen et al., 2015). The morphological structure of ECM allows the characterisation of individual root tips that consists of single fungal species. Previous studies have attributed categorical trait information, usually extracted from databases, to each ECM fungal taxa (Aguilar-Trigueros et al., 2014; Kjøller et al., 2012) thereby ignoring the intraspecific variation and plasticity of these traits. As far as we know, only one recent study (Courty et al., 2016) has used direct trait characterisation of individual ECM root tips to develop a trait-based analysis. In that work, the authors demonstrated that extracellular enzyme traits at ECM fungal community level can be driven by the soil nutrient status.

Studies on ECM functional diversity have mainly focused on the impact of soil nutrient status and the natural succession of ECM fungal communities (Clemmensen et al., 2015; Kjøller et al., 2012; Moeller et al., 2014; Suz et al., 2014). However, the effect of trace elements, mainly heavy metals, on ECM fungal community composition and diversity has been scarcely studied and the results are controversial. Hui et al. (2011) and Op De Beeck et al. (2015) did not find any effect of heavy metal contamination on ECM taxonomic diversity but noted a shift in the species composition of their communities. In contrast, Sousa et al. (2014) found both, an effect on community composition and an increase in ECM fungal diversity in Cd-contaminated plots. However, Huang et al. (2012) did not find a clear effect of the contamination neither on community composition nor at the taxonomic richness level. Despite some influences on taxonomic diversity, there exists a gap of knowledge on how such kind of anthropogenic impact 
113 affects the functional diversity of ECM fungal communities. Trace elements are likely to filter

114 against the ECM fungal species spreading more intensively in soils (those producing emanating

115 hyphae and/or rhizomorphs) due to an increased exposure to trace element toxicity (Pawlowska

116 and Charvat, 2004). In addition, increased melanisation of ECM fungal communities would be

117 expected as a consequence of the known protective effect of melanin against heavy metals (Gadd

118 and Rome, 1988; Galli et al., 1994).

Here we determined hyphal exploration types and melanisation level as traits of ECM fungal

121 species, molecularly identified, associated with holm oak (Quercus ilex subsp. ballota) in a

122 restored trace element contaminated site (Guadiamar River valley, South of Spain). We

123 quantified exploration type by microscopically confirming the presence of emanating hyphae and

124 rhizomorphs on single ECM root tips. Our hypotheses were that: i) higher concentrations of trace

125 element in soil reduce the taxonomic diversity of ECM fungal species and shifts the community

126 composition; ii) there is an effect of trace element contamination on the community mean traits

127 towards shorter exploration types and more melanised fungi; iii) we expect that trace element

128 contamination reduces the trait dispersion in ECM fungal communities, since it acts as a filter of

129 species according to their traits.

\section{2. Material and Methods}

132 2.1. Study area

133 In 1998 a mine spill contaminated $55 \mathrm{~km}^{2}$ of the Guadiamar River valley, a traditional mining 134 area in the south of Spain (Grimalt et al., 1999). The spilled acid water and sludge included a 135 variety of trace elements, with high concentrations of several highly toxic heavy metals and 

147 contaminated surface.

The affected area had two contrasting geologically-based zones (Northern and Southern), that were remediated following the same criteria. Typical bedrock types at the Northern zone are

metalloids, such as $\mathrm{As}, \mathrm{Cu}, \mathrm{Cd}, \mathrm{Hg}, \mathrm{Pb}, \mathrm{S}$ and $\mathrm{Zn}$ (Cabrera et al., 1999). During the following months, the sludge and the upper layers of contaminated soil were mechanically removed, and lime and organic amendments were added to immobilise remaining heavy metals. The stochastic nature of the contamination event and the different broad remediation tasks caused the remaining trace element concentrations in the soil to be unevenly distributed along the river corridor (Burgos et al., 2008; Domínguez et al., 2016). The area was finally remediated and afforested with autochthonous woody plant species, and legally protected as the Guadiamar Green Corridor (Domínguez et al., 2008). Only two patches unaffected by the mine spill were included in the reforestation program and planted with identical vegetation, one in the north of the dam breakdown, to allow connection of the corridor with other natural areas, and one in the south of the corridor, where an entire piece of land was expropriated including contaminated and non-

slate and schist, and it is characterised by the presence of naturally acidic soils. This zone comprises the area with the highest soil pollution levels due to its proximity to the mining activities. As a result of the remediation tasks, the soil structure was dramatically affected. The geology at the Southern zone (further than $15 \mathrm{~km}$ from the tailings dam) is characterised by the presence of limestone and calcarenite, with associated neutral to calcareous loam soils. Clean-up operations in this zone included the removal of a fine layer of the polluted topsoils, less aggressive in comparison to the clean-up of the Northern zone (Domínguez et al., 2016). Both zones (northern and southern) shared a similar soil texture (see Table S1 for details and soil 
159

160

161

162

163

164

165

166

167

168

169

170

171

172

173

174

175

176

177

178

179

180

181

classification). Climatic conditions are typical of a Mediterranean area with mild rainy winters and warm dry summers. Average annual temperature is $19^{\circ} \mathrm{C}$ (minimum monthly mean of $9^{\circ} \mathrm{C}$ in January, and maximum of $27^{\circ} \mathrm{C}$ in July) and annual average rainfall is $484 \mathrm{~mm}$ which define a potential vegetation dominated by sclerophyllous Mediterranean forests with the ectomycorrhizal holm oak (Quercus ilex subsp. ballota) as the most representative species. The area covered by the toxic flood was agricultural, however patches of agro-forest (Quercus ilex) and natural Mediterranean vegetation were closely distributed along the corridor ranging from hundreds of meters to one km maximum distance.

\subsection{Sample design, collection and processing}

Four different areas were sampled: two acidic in the Northern zone, one affected by the mine spill and the other unaffected, and two calcareous in the Southern zone, also affected and unaffected by the mine spill (Supporting Information Fig. S1). The choice of these four sampling sites made possible to construct a gradient of contamination availability due to different exposure to contamination and the variability across sites (dependent on the original soil nature -slightly acidic vs. calcic-), that makes harmful effects of contamination vary (as shown by Domínguez et al. 2017). The selection of sites were also hampered by the low availability of sites in which enough trees got established and had a similar spatial distribution (tree mortality rates were high the first two years after plantation, see Domínguez et al., 2010).

\section{Our sampling was focused in sampling and characterizing individual holm oaks due to its} constant presence all along the corridor and its representativeness of this dry Mediterranean region. All trees had been planted at the same time and from similar seed provenance. Keeping 
182 the host species constant, we could focus on the soil variability across the studied area, thus

183 excluding other confounding factors such as plant host identity and age (Albornoz et al., 2016;

184 Davey et al., 2015). Ten trees were randomly selected in each site (Supporting Information Fig.

185 S1 and Table S1 for geographical coordinates). In April 2016, roots of trees were sampled by

186 carefully tracing them from the stem of the tree in the four cardinal directions and ca. $200 \mathrm{~g}$ root

187 material was collected from each direction, i.e. subsamples. Soil samples $(0-20 \mathrm{~cm}$ depth) were

188 taken with an auger from the four directions under each tree canopy projection, and were pooled

189 to a total of $500 \mathrm{~g}$ to make a composite sample per tree.

190

191 2.3. Soil analyses

192 All soil samples were air-dried and sieved to $<2 \mathrm{~mm}$ for physico-chemical analysis. Soil $\mathrm{pH}$ was

193 measured in a 1:2.5 soil-water suspension after shaking for $30 \mathrm{~min}$. Total $\mathrm{C}$ and $\mathrm{N}$ content was

194 determined using a Flash HT Plus elemental analyser. Carbonate content was measured by the

195 manometric method (Demolon and Leroux, 1952); soil organic C was then calculated as the

196 difference between total $\mathrm{C}$ and the $\mathrm{C}$ contained in carbonates. Ammonium and nitrate were

197 extracted by $1 \mathrm{M} \mathrm{KCl}$ and determined by multiparametric Bran-Luebbe autoanalyser (Maynard et

198 al., 2007). Olsen method (Olsen et al., 1954) was used for available P estimation in neutral and

199 basic soils and Bray method was used in acidic soils (Bray et al., 1945). Available K, Ca and Mg

200 were extracted with $1 \mathrm{M}$ ammonium acetate and determined by atomic absorption

201 spectrophotometry. Sulphur and pseudo-total trace element concentrations in soil samples

202 (ground to $<60 \mu \mathrm{m}$ ) were determined by digestion with aqua regia $\left(1: 3 \mathrm{v} / \mathrm{v}\right.$ conc. $\left.\mathrm{HNO}_{3} / \mathrm{HCl}\right)$ in a

203 Digiprep MS block digestor (SPS Science) equipped with a temperature-time programmable 
204

205 206

207

208

209

210

211

212

213

214

215

216

217

218

219

220

221

222

223

224

225

226

controller and polypropylene digestion tubes. Trace elements in extracts were determined by ICP-OES.

\subsection{Mycorrhizal determinations}

The seven longest root fragments in each of the four subsamples were selected to make a composite sample of 28 fragments per tree. The extreme left mycorrhizal root tip of each root fragment was photographed for further trait quantification (Supporting Information Methods S1) and a small portion of each individual root tip was cut and immersed separately into $10 \mu \mathrm{l}$ of Extraction Solution (Extract-N-Amp ${ }^{\mathrm{TM}}$ Plant PCR Kit by Sigma-Aldrich) for subsequent molecular identification. Photographs of individual root tips were used to record the presence/absence of emanating hyphae and rhizomorphs in each root tip. The colour of root tips was assessed in the CMYB scale using ColorPick v. 3.0 (http://www.iconico.com/colorpic/; see detailed description of methodology Supporting Information Methods S1) and the black colour content annotated for each root tip (ranging from 0 to 1). The darkness of the root tips, or the content in black colour, is directly related with the melanin content of fungi in accordance with classical visual criteria used to differentiate between melanised and non-melanised fungi (e.g.

Fernandez et al., 2016). When applying our colorimetric approach to the photographs published by Fernandez and Koide (2014), we found a high correlation between black colour and the melanin contents quantified in that publication (Supporting Information Methods S1).

\subsection{Molecular analyses}

Tubes containing individual root tips and Extraction Solution were subjected to a heat shock $\left(95^{\circ} \mathrm{C}\right.$ for $10 \mathrm{~min}, 20^{\circ} \mathrm{C}$ for $10 \mathrm{~min}$ ) followed by the addition of $10 \mu \mathrm{l}$ of Dilution Solution 
227 (Extract-N-Amp ${ }^{\text {TM }}$ Plant PCR Kit by Sigma-Aldrich) and frozen until PCR setup. PCR

228 amplification was carried out using $0.55 \mu$ of DNA template with a Illustra PureTaq Ready-To-

229 Go bead (GE Healthcare UK Limited, Buckinghamshire, UK) and $0.8 \mu \mathrm{M}$ of primers ITS1F

230 (Gardes and Bruns, 1993) and ITS4 (White et al., 1990) in a final volume of $25 \mu 1$. The

231 thermocycling program was as follows: 3 min initial denaturation at $94^{\circ} \mathrm{C} ; 35$ cycles of $30 \mathrm{~s}$

232 denaturation at $94^{\circ} \mathrm{C}, 35 \mathrm{~s}$ annealing at $53^{\circ} \mathrm{C}$ and 1 min elongation (increased in $5 \mathrm{~s}$ each cycle)

233 at $72^{\circ} \mathrm{C}$; and a 4 min final elongation (as described by Suz et al., 2014). PCR products were

234 purified using MEGAquick-spin (Intron Biotechnology, South Korea) and Sanger sequenced in

235 the Unidad de Genómica y Síntesis de DNA, Instituto de Biomedicina y Parasitología López

236 Neyra, CSIC (Granada, Spain). Sequence chromatograms were checked individually and those

237 presenting double peaks, i.e. containing more than one fungal sequence, were discarded. In these

238 cases a new root tip was picked up randomly from the root sample to ensure a minimum number

239 of sequences per root sample. The remaining sequences were blasted against the UNITE

240 database (Koljalg et al., 2005) and those found corresponding to ECM fungi were grouped by

241 genera or family. Sequences in each taxonomical group were aligned separately using MAFFT v.

2427 (Katoh and Standley, 2013) and clustered in MOTHUR v. 1.35 .1 (Schloss et al., 2009) at a

$24397 \%$ cut-off to delimitated Operational Taxonomic Units (OTU). DNA sequences were

244 compared against the UNITE database (Koljalg et al., 2005) for their taxonomic placement and

245 Species Hypothesis determination. ECM fungal sequences were deposited in GenBank

246 (http://www.ncbi.nlm.nih. gov/genbank/) under accession numbers MG273770-MG274263. 
249 The whole analysis was based in the use of continuous data coming from the individual

250 characterization of holm oak trees. For a broad characterization of study plots, a principal

251 components analysis was carried out after log-transforming of trace element and soil variables.

252 Differences in abiotic and biotic (i.e. ECM fungal traits) variables across plots were assessed by

253 ANOVA after checking for normality and homoscedasticity. Tukey’s Honest was used as post

254 hoc test. Non-normal variables were log or square root transformed. Variables that even when

255 transformed were not normally distributed were analysed by non-parametric Kruskal Wallis test

256 with pairwise Dunn test corrected using Bonferroni as post hoc.

257

258 The OTU abundance data matrix was constructed based on the number of root tips where each

259 species was identified. A rarefaction analysis was carried out to ensure a high and even coverage

260 of the total diversity of OTUs in each plot. The abundance matrix was Hellinger transformed for

261 subsequent analyses (Legendre and Gallagher, 2001). Species richness (S), Chao1 and Simpson

262 (1-D) indices were calculated as alpha diversity measures.

264 An OTU $\times$ trait matrix was constructed by calculating the frequency of emanating hyphae and 265 rhizomorphs in the total root tips of each ECM fungal OTU. The black colour percentage was 266 used as a proxy of melanin content and its value for each species was calculated as the average of 267 the black component across all identified root tips per each OTU. To scale up from OTU to 268 community level, all these traits were weighted by the relative abundance of each OTU to 269 calculate community-weighted means (CWMs) of mycorrhizal traits for each tree (called fixed 270 trait averages by Lepš et al., 2011). 
272 A Variation Partitioning approach (Legendre and Legendre, 1998) was used to assess the

273 influence of soil variables and trace elements on species (species-based RDA) and trait

274 distribution (CWM-based RDA) (Kleyer et al., 2012). For that, every abiotic variable was log

275 transformed, with the exception of $\mathrm{pH}$, and the Hellinger transformed OTU matrix and the CWM

276 matrix were used as response matrices for the species- and CWM-based RDAs, respectively. A

277 previous selection of variables was carried out by stepwise model building for constrained

278 ordination methods (Blanchet et al., 2008) with backward and forward selection to include

279 important variables only. Since the objective of this analysis was to quantify the relative

280 contribution to OTU and CWM distribution of soil background variables, trace elements and

281 their shared covariation, the approach was applied separately for each group of soil factors (soil

282 background variables and trace elements). For each subset of variables selected by the models,

283 the variance inflation factors (VIF) were calculated (Gross, 2003), and variables above VIF=5

284 were removed. To control for the effect of spatial distribution of samples, principle coordinates

285 of neighbour matrices (PCNM approach; Borcard and Legendre 2002) were calculated. The

286 resulting PCNM axes were subjected to the same selection as described for soil and trace

287 element variables, and those found to significantly influence the OTU or CWM distribution were

288 selected. Every selected variable, either from soil, trace elements or spatial components, were

289 feed to the variation partitioning analysis. To visualise the identified trends, an RDA ordination

290 was carried out including all selected variables.

292 To assess the significance of each of the soil background variables and trace elements on fungal 293 trait values, RLQ and fourth-corner analyses were performed (Legendre et al., 1997; Dray and 294 Legendre, 2008). This method directly compares the three matrices: environmental, species 
295 abundance and species traits. Effects were calculated using permutation model \#6 with 9999

296 permutations, which is a combination of models \#2 (permutes values of sites) and \#4 (permutes

297 values of species) which does not have an inflated type I error (Dray and Legendre, 2008; ter

298 Braak et al., 2012). False discovery rate correction for multiple testing (Benjamini and Yekuteli,

299 2001) was applied.

300

301 In order to obtain insights into the rules governing ECM fungal community assembly, the trait

302 distribution across OTUs in communities was compared with random expectations. For that,

303 standardised effect size of mean pairwise distance (ses.mpd) between OTUs in each community

304 was calculated by using the OTU abundance data matrix and a Euclidean trait distance matrix

305 between OTUs. Independent swap algorithm was used to generate null communities (Gotelli,

306 2000). Ses.mpd varies from -1 to 1 , where negative values mean trait convergence and positive

307 values trait divergence. Relationships of ses.mpd with soil factors were checked by Pearson

308 correlation applying a false discovery rate correction for multiple testing (Benjamini \& Yekuteli, 309 2001).

311 All statistics were carried out in R software v 3.3.2 (R Development Core Team) using vegan

312 (Oksanen et al., 2012), picante (Kembel et al., 2010) and ade4 (Dray and Dufour, 2007)

313 packages.

314

315 3. Results

316

3.1. Soil abiotic factors 
317 The two sites affected by the mine spill (CN and CS) showed significantly higher values of most

318 of the measured pseudo-total trace element concentrations ( $\mathrm{As}, \mathrm{Cd}, \mathrm{Cu}, \mathrm{Pb}, \mathrm{S}$ and $\mathrm{Zn}$ ) in relation

319 to the non-affected sites (UN and US) (Table 1, Fig. 1). However, when looking at other soil

320 variables, the sites from the northern zone (CN and UN) had relatively similar values of $\mathrm{pH}, \mathrm{NH}_{4}$

321 and total $\mathrm{N}$ - more acidic and N-rich -, than those from the southern zone, CS and US (Table 1,

322 Fig. 1).

323

324

\subsection{ECM fungal community composition, taxonomic and functional diversity}

325 From a total of 1,120 sampled root tips, 494 produced successful PCR amplifications and were 326 identified as ECM fungal species. They were classified into 55 different OTUs belonging to 14

327 families and 19 genera (Supporting Information Table S2). There were two species which

328 dominated the communities: Hebeloma cavipes and Thelephora terrestris, representing $16.4 \%$

329 and $12.3 \%$ of sequences, respectively. Most of the species occurred on less than two trees

330 (Supporting Information Table S2). Rarefaction analysis showed that for each site, most of the 331 OTU richness was recorded (Supporting Information Fig. S2). The mean number of ECM fungal

332 species per tree was 3.8, the estimated Chao richness was 4.9 species per tree, and the Simpson

333 dominance index averaged 0.6. For the three diversity measures there were no significant

334 differences between sites or contamination levels.

336 The frequencies of emanating hyphae and rhizomorphs across OTUs ranged from 0 to $100 \%$, 337 and melanisation from 64 to $94.7 \%$ (Supporting Information Table S3). Among the three most 338 abundant families (Cortinariaceae, Russulaceae and Thelephoraceae), OTUs in the 339 Cortinariaceae family showed the lower variability in the three studied traits (emanating hyphae 
(\%): 66.6 to 100 ; rhizomorphs (\%): 0 to 66.6 ; melanisation (\%): 64.6 to 72.9$)$. OTUs belonging

to the other two dominant families were highly variable in terms of emanating hyphae and rhizomorphs (ranging $0 \%$ to $100 \%$ ), while melanisation spanned in the range between $70 \%$ and $94.7 \%$. The two most dominant species (H. cavipes and T. terrestris) had similar rhizomorph frequency and melanisation (around $12 \%$ and $68 \%$, respectively), but $H$. cavipes showed emanating hyphae more frequently $(95.1 \%)$ than $T$. terrestris $(88.5 \%)$. The trait ranges exhibited by the detected ECM fungal species were congruent with the available descriptions of species and genera (Deemy database, see Supporting Information Table S3 for a comparison).

\subsection{Effect of abiotic variables on ECM fungal community composition}

According to the selected RDA models, the variables that best explained ECM fungal community variability (OTU matrix) were available $\mathrm{Ca}$, organic $\mathrm{C}$ and total $\mathrm{C}$ among soil background variables, and $\mathrm{Cu}, \mathrm{Ni}, \mathrm{S}$ and $\mathrm{Zn}$ among trace elements (Fig. 2a; Supporting Information Table S4). Sulphur was removed from the subsequent analysis due to a high VIF result. Two PCNM axes were found to influence OTU community composition. The variation partitioning approach revealed that soil background variables and their covariation with trace element explained 8.36 and $0.55 \%$, respectively; meanwhile trace elements alone explained 3.82 $\%$ of variation in the model (Fig. 2a, pie chart). The spatial distribution of ECM communities explained a $2.06 \%$ alone, and shared $2.86 \%$ with soil background and trace element variables. There was no sign of collinearity between variables in the variation partitioning analysis. The two most abundant species, $H$. cavipes and $T$. terrestris, showed contrasting patterns regarding the trace element and $\mathrm{Ca}$ gradients, respectively, in the RDA ordination (Fig. 2a). H. cavipes 
362

363 364 $2 b)$.

seemed to be related to lower concentrations of $\mathrm{Cu}, \mathrm{Zn}$ and total $\mathrm{C}$, and higher concentrations of Ni. T. terrestris appeared to be related with lower concentrations of $\mathrm{Ca}$, as shown in Fig. 2a.

\subsection{Effect of abiotic variables on ECM fungal community traits}

The RLQ analysis showed a significant effect of the abiotic environment on the community composition by an interaction with species traits (model \#2, $P=0.006$; model \#4, $P<0.001$ ). Significant negative interactions were found between CWM of emanating hyphae and rhizomorphs and some trace elements and total C (displayed in Table 2). On the other hand, melanisation significantly interacted with $\mathrm{CaCO}_{3}$.

The soil background variables that best explained CWM traits distribution included $\mathrm{CaCO}_{3}$, total C, organic C and available P (Fig. 2b; Supporting Information Table S4), however, total C was removed from subsequent analysis due to a high VIF. On the other hand, among the trace elements, $\mathrm{As}, \mathrm{Cd}$ and $\mathrm{Cu}$ best explained the variation of fungal community traits. $\mathrm{Cu}$ was finally removed due to a high VIF. No spatial variables (PCNM axes) were found to significantly explain any variation in trait distribution and were not included in the variation partition analysis. When partitioning the variation into trace element and soil background variables, trace elements explained $15.46 \%$ of the total variation, soil background $7.54 \%$ and their covariation $6.59 \%$ of the trait variability (Fig. 2b, pie chart). In agreement with the fourth corner analysis (Table 2), emanating hyphae and rhizomorphs appeared negatively related to trace element concentrations and organic $\mathrm{C}$. Meanwhile, melanisation and $\mathrm{CaCO}_{3}$ showed a clear positive covariation (Fig. 
The analysis of trait distribution (ses.mpd values) across sites showed no differences among them. The correlation of ses.mpd values of fungal traits with the selected variables in the RDA models (As, $\mathrm{Cd}, \mathrm{CaCO}_{3}$, organic $\mathrm{C}$ and available $\mathrm{P}$ ) showed that rhizomorph ses.mpd negatively correlates with Cd concentration (Table 3), which means that the ECM species in communities became more similar with increasing $\mathrm{Cd}$ concentration. No other significant correlations were found, however emanating hyphae ses.mpd showed a similar magnitude in its positive correlation coefficient with Cd (Table 3).

\section{Discussion}

Overall, our trait-based approach proved to be a highly useful tool to quantify potential effects of an environmental disturbance on the functional diversity of natural microbial communities.

Firstly, because our trait measurements were consistent with the previous descriptions of species, but because, in addition to the reliability, it allows for a numeric quantification of explorationtype related traits and melanisation degree which was lacking in previous categorical classifications. Furthermore, the analyses showed, as expected, an effect of trace element contamination on the functional traits of ECM fungal communities.

\subsection{Effect of contamination on ECM fungal community diversity and structure}

Soil trace element contamination had no effect on ECM fungal richness. This fact has to be discussed due to the inconsistency of previous results. Some authors did find a negative impact of heavy metal contamination on ECM fungal diversity (Huang et al., 2014; Ruotsalanien et al., 2009; Staudenrausch et al., 2005). In contrast, other studies missed such an effect, in agreement with our results (see Hui et al., 2011; Op de Beeck et al., 2015). In our case, the relatively young 
age of the trees, all of them planted only 17 years ago, could increase the chances that stochastic effects, i.e. priority effects, were acting on the community assembly of the ECM fungal communities. This fact would explain two results: on one hand, the relatively low ECM species richness (average of 3.8 species per tree) in comparison with previous studies in near mature Mediterranean forests (evergreen Quercus suber) which averaged 6.3 species per tree (Aponte et al., 2010). This trend is in agreement with the known increase in ECM species richness during ecosystem development as observed by Visser (1995) or Wallander et al. (2010). On the other hand, the effect of soil background variables and trace element contamination on the ECM fungal community composition was relatively low (a small percentage of variation in species composition was explained by these variables). This is consistent with a primary successional scenario where stochastic processes such as dispersal and/or priority effects drive the community assembly (Jumponen, 2003; Kennedy et al., 2009; Peay and Bruns, 2014) and thus blur the deterministic effects caused by soil factors, i.e. the proportion of community composition explained by the soil environment or its effect on species richness. Indeed, although low as well, a certain proportion of the variation of the OTU community composition was found to depend on the spatial position, which is a sign of a stochastic process influencing community assembly. On the other hand, other environmental factors not measured in this study, such as the relative influence of the seasonal river floods on different sites, could be responsible for the proportion of unexplained variance in community composition.

Despite the variance explained by soil factors being limited, soil background variables and trace elements explained a similar proportion of the variation in species composition. Previous studies of ECM fungal communities have shown the important influence of nutrient-related variables, 
431 432 (Twieg et al., 2009). In our study, the two most frequent ECM species, H. cavipes and T.

433

434

435

436

437

438

439

440

441

442

443

444

445

446

447

448

449

450

451

452

453

such as total $\mathrm{C}$ or organic $\mathrm{C}$ in soil, in the determination of $\mathrm{ECM}$ fungal community composition terrestris, were related to two independent abiotic gradients: $H$. cavipes to a trace element concentration gradient, and T. terrestris to a gradient in Ca concentration (likely related to the $\mathrm{CaCO}_{3}$ and $\left.\mathrm{pH}\right)$. This fact would explain why the variance in community composition was equally explained for each group of variables, as each of these groups explains the presence of one of the two most abundant ECM fungal species. Indeed, this result resembles the results by Op de Beeck et al. (2015) who also found that communities of ECM fungi were driven according to two environmental gradients: one responding to heavy metal contamination levels and the other driven by $\mathrm{Fe}, \mathrm{Mn}, \mathrm{Mg}$ and $\mathrm{K}$.

\subsection{Effect of contamination on mean fungal trait values}

The effect of contamination was visible both in terms of the mean trait values of communities and the trait similarity across species in communities. Both rhizomorph and emanating hyphae frequency were found to be negatively associated with the concentration of some trace elements, which indicates a suppressive effect of the contamination on extramatrical mycelium growth. This effect has previously been found in controlled experiments, and varies across ECM fungal species (Qi et al., 2016). At the same time, the recorded patterns for the exploration-type related traits, particularly the relationship between emanating hyphae and total $\mathrm{C}$, are also highly congruent with the known variation of exploration type in response to changes in $\mathrm{N}$ sources in the soil, i.e. a change from inorganic to organic $\mathrm{N}$ sources will reduce the development of extramatrical mycelium (Hobbie and Agerer, 2010; Lilleskov et al., 2002; 2011). Previous studies have pointed out the capacity of melanin to biosorb $\mathrm{Cu}$ and reduce its environmental 
454 toxicity (Gadd and Rome, 1988), and that dark Ascomycota species usually are more resistant to 455 heavy metal contamination than Basidiomycota (Likar and Regvar, 2013). The hypothesis that 456 the degree of melanisation would increase with heavy metal concentration has to be rejected for

457 this dataset since we did not record an increase in the black colour of ECM fungi present in 458 contaminated sites compared with non-contaminated ones. The relationship between black 459 colour of ECM fungal species and $\mathrm{CaCO}_{3}$ could be the result of other biochemical interactions 460 since melanin seems to be involved in the $\mathrm{Ca}^{2+}$ regulation of the cells (Bush et al., 2007). In the 461 present study, the variation in CWM fungal traits explained by trace element concentrations

462 doubled the variation explained by soil background variables. These effects were also 463 independent of the spatial distribution of the samples, excluding any potential site effect in the 464 results. This fact, together with the smaller overall variance explained in the case of the OTU 465 matrix, highlights the interest of this trait-based approach to explain the consequences of trace 466 element contamination on ECM fungal communities.

\subsection{Ecological processes driving ECM fungal community assembly}

469 The trait dispersion of species within communities was driven mainly by soil contamination and

470 not by the nutrient status of the soil. The increase in Cd concentrations made species in ECM

471 fungal communities become more similar in terms of presence of rhizomorphs. This reveals the

472 potential environmental filtering that heavy metal contamination can have on the trait

473 composition of ECM fungal communities. While species richness was similar across the studied

474 sites, the increase in trait convergence indicates a reduction in the functional diversity of the 475 community (Bässler et al., 2015) in response to soil contamination. Although we also found an 476 average reduction in the emanating hyphae with increasing contamination levels, the tendency, 
477 marginally significant, with increasing contamination was a divergence in the frequency of

478 emanating hyphae produced by species in the same community. This is not in agreement with an

479 environmental filtering, as suggested for rhizomorphs, but could indicate that competition

480 between species is selecting species that differ in this trait. This could be explained by an

481 interaction between the two traits: once the community has been filtered according to the

482 production of rhizomorphs, the remaining subset of species is selected against biotic interactions,

483 i.e. competition, as observed for example by Ingram and Shurin (2009).

484

485 The consequences of the reduction in the functional diversity of ECM fungal communities for 486 plant and ecosystem functioning might depend on the specific traits affected. For ECM fungi it is

487 known that the decomposition rate of their biomass is very dependent on melanin content and 488 hyphal architecture (i.e. hydrophobic rhizomorphs versus hydrophilic feeder hyphae, Fernandez 489 et al., 2016), which thus influences C storage in soil (Clemmensen et al., 2015). Additionally, 490 these two traits also have an important role in water stress alleviation for plants (Fernandez and 491 Koide, 2013), which may have important consequences for host fitness, particularly in

492 Mediterranean environments.

493

494 4.4. Conclusions

495 In this study, we demonstrated that ECM functional traits correlated better with soil 496 contamination than fungal taxonomic diversity or community structure. Thus, adding trait-based 497 approaches to the description of ECM fungal communities facilitates a better understanding of 498 the potential consequences of environmental degradation on ecosystem functioning. The often 499 contradictory results of the effect of environmental impact on ECM fungal communities at the 
500 species level, both in terms of community compositions and taxonomic diversity, can be

501 overcome by these functional approaches. However, more research is needed to show how the

502 community trait changes influences the functionality of ecosystems.

504 Acknowledgements

505 We thank Thomas Ashley for comments on the manuscript and Teo Lemaitre for technical

506 assistance. This work was supported by European Union Seventh Framework Programme

507 (FP7/2007-2013) [grant number 603498 - RECARE]; Spanish Ministry of Economy and

508 Competitiveness [grant number CGL2014-52858-R - RESTECO]; Spanish National Research

509 Programme - European Union (Feder) [grant number CGL2015-69118-C2-2-P - COEXMED-II].

510 During manuscript preparation, ALG was supported by European Union's Horizon 2020 Marie

511 Curie Individual Fellowship [grant number 708530 - DISPMIC]. MTD is thankful the University

512 of Sevilla for a postdoctoral fellowship (V Plan Propio de Investigación).

\section{Competing interest statement}

515 The authors declare no competing interests. 


\section{References}

517 Agerer, R. 2001. Exploration types of ectomycorrhizae: A proposal to classify ectomycorrhizal

518 mycelial systems according to their patterns of differentiation and putative ecological

519 importance. Mycorrhiza, 11, 107-114. doi:10.1007/s005720100108

520 Agerer, R. 2006. Fungal relationships and structural identity of their ectomycorrhizae.

521 Mycological Progress, 5, 67-107. doi: 10.1007/s11557-006-0505-x

522 Aguilar-Trigueros, C.A., Powell, J.R., Anderson, I.C., Antonovics, J., Rillig, M.C. 2014.

523 Ecological understanding of root-infecting fungi using trait-based approaches. Trends in Plant

524 Science, 19, 432-438. doi:10.1016/j.tplants.2014.02.006

525 Albornoz, F.E., Teste, F.P., Lambers, H., Bunce, M., Murray, D.C., White, N.E., Laliberté, E.

526 2016. Changes in ectomycorrhizal fungal community composition and declining diversity along

527 a 2-million-year soil chronosequence. Molecular Ecology, 25, 4919-4929.

528 doi:10.1111/mec.13778

529 Aponte, C., García, L.V., Marañón, T., Gardes, M. 2010. Indirect host effect on ectomycorrhizal 530 fungi: Leaf fall and litter quality explain changes in fungal communities on the roots of co-

531 occurring Mediterranean oaks. Soil Biology \& Biochemistry, 42, 788-796.

532 Bardgett, R.D., Mommer, L., De Vries, F.T. 2014. Going underground: root traits as drivers of 533 ecosystem processes. Trends in Ecology \& Evolution, 29, 692-699. doi:

$534 \quad 10.1016 /$ j.tree.2014.10.006

535 Bässler, C., Heilmann-Clausen, J., Karasch, P., Brandl, R., Halbwachs, H. 2015.

536 Ectomycorrhizal fungi have larger fruit bodies than saprotrophic fungi. Fungal Ecology, 17, 205-

537 212. doi: 10.1016/j.funeco.2014.06.005 
Benjamini, Y., Yekuteli, D. 2001. The Control of the False Discovery Rate in Multiple Testing under Dependency. The Annals of Statistics, 29, 1165-1188.

Blanchet, F.G., Legendre, P., Borcard, D. 2008. Forward selection of explanatory variables. Ecology, 89, 2623-2632. doi: 10.1890/07-0986.1

Bray, R.H., Kurtz, L.T. 1945. Determination of total, organic and available forms of phosphorus in soils. Soil Science, 59, 39-45.

Bu, W., Schmid, B., Liu, X., Li, Y., Härdtle, W., von Oheimb, G., Liang, Y., Sun, Z., Huang, Y. et al. 2017. Inter- and intraspecific variation in specific root length drives aboveground biodiversity effects in young experimental forest stands. Journal of Plant Ecology, 10, 158-169. doi:10.1111/j.1399-0012.2012.01641.x

Burgos, P., Madejón, E., Pérez de Mora, A., Cabrera, F. 2008. Horizontal and vertical variability of soil properties in a trace element contaminated area. International Journal of Applied Earth Observation and Geoinformation, 10, 11-25. doi:10.1016/j.jag.2007.04.001

Bush, W.D., Simon, J.D. 2007. Quantification of Ca2+ binding to melanin supports the hypothesis that melanosomes serve as functional role in regulating calcium homeostasis. Pigment Cell Research, 20, 134-139. doi: 10.1111/j.1600-0749.2007.00362.x

Cabrera, F., Clemente, L., Díaz Barrientos, E., López, R., Murillo, J.M. 1999. Heavy metal pollution of soils affected by the Guadiamar toxic flood. Science of the Total Environment, 242, 117-129. doi: 10.1016/S0048-9697(99)00379-4

57 Cadotte, M.W., Carscadden, K., Mirotchnick, N. 2011. Beyond species: Functional diversity and the maintenance of ecological processes and services. Journal of Applied Ecology, 48, 10791087. doi:10.1111/j.1365-2664.2011.02048.x 
Clemmensen, K.E., Bahr, A., Ovaskainen, O., Dahlberg, A., Ekblad, A., Wallander, H., Stenlid, J., Finlay, R.D., Wardle, D.A., Lindahl, B.D. 2013. Roots and associated fungi drive long-term carbon sequestration in boreal forest. Science, 339, 1615-1618. doi: 10.1126/science.1231923

Clemmensen, K.E., Finlay, R.D., Dahlberg, A., Stenlid, J., Wardle, D.A. 2015. Carbon sequestration is related to mycorrhizal fungal community shifts during long-term succession in boreal forests. New Phytologist, 205, 1525-1536. doi: 10.1111/nph.13208

Cordero, R.J. 2017. Melanin for space travel radioprotection. Environmental Microbiology, 19: 2529-2532. doi: 10.1111/1462-2920.13753

Courty, P.E., Munoz, F., Selosse, M.A., Duchemin, M., Criquet, S., Ziarelli, F., Buée, M., Plassard, C., Taudière, A., Garbaye, J., et al. 2016. Into the functional ecology of ectomycorrhizal communities: environmental filtering of enzymatic activities. Journal of Ecology, 104, 1585-1598. doi:10.1111/1365-2745.12633

Crowther, T.W., Maynard, D.S., Crowther, T.R., Peccia, J., Smith, J.R., Bradford, M.A. 2014. Untangling the fungal niche: the trait-based approach. Frontiers in Microbiology, 5, article 579. doi: 10.3389/fmicb.2014.00579

Davey, M., Blaalid, R., Vik, U., Carlsen, T., Kauserud, H., Eidesen, P.B. 2015. Primary succession of Bistorta vivipara (L.) Delabre (Polygonaceae) root-associated fungi mirrors plant succession in two glacial chronosequences. Environmental Microbiology, 17, 2777-2790. doi: $10.1111 / 1462-2920.12770$

Demolon, A., Leroux, D. 1952. Guide pour l'etude experimental des sols. Gauthier-Villars , Paris.

De la Riva, E.G., Marañón, T., Pérez-Ramos, I.M., Navarro-Fernández, C.M., Olmo, M., Villar, R. 2017. Root traits across environmental gradients in Mediterranean woody communities: are 
they aligned along the root economics spectrum? Plant and Soil. doi: 10.1007/s11104-017-3433-

$584 \quad 4$

585 Díaz, S., Cabido, M. 2001. Vive la difference: plant functional diversity matters to ecosystem

586 processes. Trends in Ecology \& Evolution, 16, 646-655. doi: 10.1016/S0169-5347(01)02283-2

587 Díaz, S., Lavorel, S., de Bello, F., Quétier, F., Grigulis, K., Robson, T.M. 2007. Incorporating 588 plant functional diversity effects in ecosystem service assessments. Proceedings of the National 589 Academy of Sciences of the United States of America, 104, 20684-20689. doi: 10.1073/pnas.0704716104

Domínguez, M.T., Marañón, T., Murillo, J.M., Schulin, R., Robinson, B.H. 2008. Trace element 592 accumulation in woody plants of the Guadiamar valley, SW Spain: a large scale phytomanagement case study. Environmental Pollution, 152, 50-59. doi:

$594 \quad 10.1016 /$ j.envpol.2007.05.021

Domínguez, M.T., Madejón, P., Marañón, T., Murillo, J.M. 2010. Afforestation of a trace-

596 element polluted area in SW Spain: Woody plant performance and trace element accumulation.

597 European Journal of Forest Research, 129, 47-59. doi:10.1007/s10342-008-0253-3

598 Domínguez, M.T., Alegre, J.M., Madejón, P., Madejón, E., Burgos, P., Cabrera, F., Marañón, T., 599 Murillo, J.M. 2016. River banks and channels as hotspots of soil pollution after large-scale 600 remediation of a river basin. Geoderma, 261, 133-140. doi: 10.1016/j.geoderma.2015.07.008

601 Domínguez, M.T., Montiel-Rozas, M.M., Madejón, P., Diaz, M.J., Madejón, E. 2017. The 602 potential of native species as bioenergy crops on trace-element contaminated Mediterranean 603 lands. Science of the Total Environment, 590-591, 29-39. doi:10.1016/j.scitotenv.2017.03.018 604 Dray, S., Dufour, A.B. 2007. The ade4 Package: Implementing the Duality Diagram for 605 Ecologists. Journal of Statistical Software, 22, 1-20. doi: 10.18637/jss.v022.i04 
606

607

608

609

610

611

612

613

614

615

616

617

618

619

620

621

622

623

624

625

626

627

628

Dray, S., Legendre, P. 2008. Testing the species traits environment relationships: The fourthcorner problem revisited. Ecology, 89, 3400-3412. doi:10.1890/08-0349.1

Fernandez, C.W., Koide, R.T. 2014. Initial melanin and nitrogen concentrations control the decomposition of ectomycorrhizal fungal litter. Soil Biology and Biochemistry, 77, 150-157. doi:10.1016/j.soilbio.2014.06.026

Fernandez, C.W., Koide, R.T. 2013. The function of melanin in the ectomycorrhizal fungus Cenococcum geophilum under water stress. Fungal Ecology, 6, 479-486. doi:10.1016/j.funeco.2013.08.004

Fernandez, C.W., Langley, J.A., Chapman, S., McCormack, M.L., Koide, R.T. 2016. The decomposition of ectomycorrhizal fungal necromass. Soil Biology and Biochemistry, 93, 38-49. doi:10.1016/j.soilbio.2015.10.017

Galli, U., Schuepp, H., Brunold, C. 1994. Heavy-metal binding by mycorrhizal fungi. Physiologia Plantarum, 92, 364-368. doi:10.1034/j.1399-3054.1994.920224.x

Gardes, M., Bruns, T.D. 1993. ITS primers with enhanced specificity for basidiomycetes application to the identification of mycorrhizae and rusts. Molecular Ecology, 2, 113-118.

Garnier, E., Navas, M.L., Grigulis, K. 2016. Plant functional diversity: Organism traits, community structure, and ecosystem properties. Oxford University Press, Oxford.

Gotelli, N.J. 2000. Null model analysis of species co-occurrence patterns. Ecology, 81, 26062621. doi: 10.1890/0012-9658(2000)081[2606:NMAOSC]2.0.CO;2

Götzenberger, L., de Bello, F., Brathen, K.A., Davison, J., Dubuis, A., Guisan, A., Leps, J., Lindborg, R., Moora, M., Partel, M., et al. 2012. Ecological assembly rules in plant communities-approaches, patterns and prospects. Biological Reviews, 87, 111-127. doi:10.1111/j.1469-185X.2011.00187.x 
629

630

631

632

633

634

635

636

637

638

639

640

641

642

643

644

645

646

647

648

649

Gould, I.J., Quinton, J.N., Weigelt, A., De Deyn, G.B., Bardgett, R.D., Seabloom, E. 2016. Plant diversity and root traits benefit physical properties key to soil function in grasslands. Ecology Letters, 19, 1140-1149. doi:10.1111/ele.12652

Grimalt, J.O., Ferrer, M., Macpherson, E. 1999. The mine tailing accident in Aznalcollar. The science of the Total Environment, 242, 3-11. doi: 10.1016/S0048-9697(99)00372-1

Gross, J. 2003. Variance inflation factors. R News, 3, 13-15.

Hobbie, E.A., Agerer, R. 2010. Nitrogen isotopes in ectomycorrhizal sporocarps correspond to belowground exploration types. Plant and Soil, 327, 71-83. doi: 10.1007/s11104-009-0032-z

Huang, J., Nara, K., Lian, C., Zong, K., Peng, K., Xue, S., Shen, Z. 2012. Ectomycorrhizal fungal communities associated with Masson pine (Pinus massoniana Lamb.) in $\mathrm{Pb}-\mathrm{Zn}$ mine sites of central south China. Mycorrhiza, 22, 589-602. doi: 10.1007/s00572-012-0436-0

Huang, J., Nara, K., Zong, K., Wang, J., Xue, S., Peng, K., Shen, Z., Lian, C. 2014.

Ectomycorrhizal fungal communities associated with Masson pine (Pinus massoniana) and white oak (Quercus fabri) in a manganese mining region in Hunan Province, China. Fungal Ecology, 9, 1-10. doi: 10.1016/j.funeco.2014.01.001

Hui, N., Jumpponen, A., Niskanen, T., Liimatainen, K., Jones, K.L., Koivula, T., Romantschuk, M., Strömmer, R. 2011. EcM fungal community structure, but not diversity, altered in a Pbcontaminated shooting range in a boreal coniferous forest site in Southern Finland. FEMS Microbiology Ecology, 76, 121-132. doi: 10.1111/j.1574-6941.2010.01038.x Ingram, T., Shurin, J.B. 2009. Trait-based assembly and phylogenetic structure in northeast Pacific rockfish assemblages. Ecology, 90, 2444-2453. doi: 10.1890/08-1841.1 
650

651

652

653

654

655

656

657

658

659

660

661

662

663

664

665

666

667

668

669

670

671

Jumpponen, A. 2003. Soil fungal community assembly in a primary successional glacier

forefront ecosystem as inferred from rDNA sequence analyses. New Phytologist, 158, 569-578. doi: 10.1046/j.1469-8137.2003.00767.x

Katoh, K., Standley, D.M. 2013. MAFFT Multiple Sequence Alignment Software Version 7:

Improvements in Performance and Usability. Molecular Biology and Evolution, 30, 772-780. doi: 10.1093/molbev/mst010

Kembel, S.W., Cowan, P.D., Helmus, M.R., Cornwell, W.K., Morlon, H., Ackerly, D.D., Blomberg, S.P., Webb, C.O. 2010. Picante: R tools for integrating phylogenies and ecology. Bioinformatics, 26, 1463-1464. doi:10.1093/bioinformatics/btq166

Kennedy, P.G., Peay, K.G., Bruns, T.D. 2009. Root tip competition among ectomycorrhizal fungi: Are priority effects a rule or an exception? Ecology, 90, 2098-2107. doi: 10.1890/081291.1

Kjøller, R., Nilsson, L.O., Hansen, K., Schmidt, I.K., Vesterdal, L., Gundersen, P. 2012.

Dramatic changes in ectomycorrhizal community composition, root tip abundance and mycelial production along a stand-scale nitrogen deposition gradient. New Phytologist, 194, 278-286. doi:10.1111/j.1469-8137.2011.04041.x

Kleyer, M., Dray, S., de Bello, F., Lepš, J., Pakeman, R.J., Strauss, B., Thuiller, W., Lavorel, S. 2012. Assessing species and community functional responses to environmental gradients: which multivariate methods? Journal of Vegetation Science, 23, 805-821. doi:10.1111/j.16541103.2012.01402.x

Kogej, T., Gorbushina, A.A., Gunde-Cimerman, N. 2006. Hypersaline conditions induce changes in cell-wall melanization and colony structure in a halophilic and a xerophilic black yeast species 
672 of the genus Trimmatostroma. Mycological Research, 110, 713-724.

673 doi:10.1016/j.mycres.2006.01.014

674 Koide, R.T., Fernandez, C., Malcolm, G. 2014. Determining place and process: Functional traits

675 of ectomycorrhizal fungi that affect both community structure and ecosystem function. New

676 Phytologist, 201, 433-439. doi:10.1111/nph.12538

677 Kõljalg, U., Larsson, K.H., Abarenkov, K., Nilsson, R.H., Alexander, I.J., Eberhardt, U., Erland,

678 S., Høiland, K., Kjøller, R., Larsson, E., et al. 2005. UNITE: a database providing web-based

679 methods for the molecular identification of ectomycorrhizal fungi. New Phytologist, 166, 1063-

680 1068. doi: 10.1111/j.1469-8137.2005.01376.x

681 Laliberté, E. 2016. Below-ground frontiers in trait-based plant ecology. New Phytologist, 213,

682 1597-1603. doi:10.1111/nph.14247

683 Lavorel, S., Garnier, E. 2002. Predicting changes in community composition and ecosystem 684 functioning from plant traits: Revisiting the Holy Grail. Functional Ecology, 16, 545-556. doi:

$685 \quad 10.1046 / \mathrm{j} .1365-2435.2002 .00664 . x$

686 Lavorel, S., Storkey, J., Bardgett, R.D., de Bello, F., Berg, M.P., Le Roux, X., Moretti, M.,

687 Mulder, C., Pakeman, R.J., Díaz, S. et al. 2013. A novel framework for linking functional

688 diversity of plants with other trophic levels for the quantification of ecosystem services. Journal

689 of Vegetation Science, 24, 942-948.

690 Legendre, P., Gallagher, E. 2001. Ecologically meaningful transformations for ordination of 691 species data. Oecologia, 129, 271-280. doi:10.1007/s004420100716

692 Legendre, P., Legendre, L. 1998. Numerical Ecology. Amsterdam, Netherlands: Elsevier 693 Science. 
Legendre, P., Galzin, R., Harmelin-Vivien, M.L. 1997. Relating behavior to habitat: solutions to

695 the fourth-corner problem. Ecology, 78, 547-562. doi: 10.1890/0012-

696 9658(1997)078\%5B0547:RBTHST\%5D2.0.CO\%3B2

697 Lepš, J., de Bello, F., Šmilauer, P., Doležal, J. 2011. Community trait response to environment:

698 disentangling species turnover vs intraspecific trait variability effects. Ecography, 34, 856-863.

699 doi: 10.1111/j.1600-0587.2010.06904.x

700 Likar, M., Regvar, M. 2013. Isolates of dark septate endophytes reduce metal uptake and 701 improve physiology of Salix caprea L. Plant and Soil, 370, 593-604. doi: 10.1007/s11104-013-

$702 \quad 1656-6$

703 Lilleskov, E.A., Hobbie, E.A., Fahey, T.J. 2002. Ectomycorrhizal fungal taxa differing in 704 response to nitrogen deposition also differ in pure culture organic nitrogen use and natural 705 abundance of nitrogen isotopes. New Phytologist, 154, 219-231. doi: 10.1046/j.1469-

$706 \quad 8137.2002 .00367 . x$

707 Lilleskov, E.A., Hobbie, E.A., Horton, T.R. 2011. Conservation of ectomycorrhizal fungi:

708 exploring the linkages between functional and taxonomic responses to anthropogenic $\mathrm{N}$

709 deposition. Fungal Ecology, 4, 174-183. doi: 10.1016/j.funeco.2010.09.008

710 López-García, Á., Azcón-Aguilar, C., Barea, J.M. 2014. The interactions between plant life form 711 and fungal traits of arbuscular mycorrhizal fungi determine the symbiotic community.

712 Oecologia, 176, 1075-1086. doi: 10.1007/s00442-014-3091-7

713 Maynard, D.G., Kalra, Y.P., Crumbaugh, J.A. 2007. Nitrate and exchangeable ammonium

714 nitrogen. In: Carter, M.R., Gregorich, E.G., eds. Soil sampling and methods of analysis (2nd 715 edition). Boca Raton, USA: CRC Press, Taylor and Francis Group, 71-80 
716

717 718

Moeller, H.V., Peay, K.G., Fukami, T. 2014. Ectomycorrhizal fungal traits reflect environmental conditions along a coastal California edaphic gradient. FEMS Microbiology Ecology, 87, 797806. doi: 10.1111/1574-6941.12265

Mulder, C., Cohen, J.E., Setälä, H., Bloem, J., Breure, A.M. 2005. Bacterial traits, organism mass, and numerical abundance in the detrital soil food web of Dutch agricultural grasslands. Ecology Letters, 8, 80-90. doi: 10.1111/j.1461-0248.2004.00704.x

Oksanen, J., Blanchet, F.G., Kindt, R. 2012. vegan: Community ecology package. Olsen, S.R., Cole, C.V., Watanabe, F.S., Dean, L.A. 1954. Estimation of available phosphorus in soils by extraction with sodium bicarbonate. USDA Circular 939. Washington DC: US gov Print Office.

Op De Beeck, M., Ruytinx, J., Smits, M.M., Vangronsveld, J., Colpaert, J.V., Rineau, F. 2015. Belowground fungal communities in pioneer Scots pine stands growing on heavy metal polluted and non-polluted soils. Soil Biology and Biochemistry, 86, 58-66. doi:

10.1016/j.soilbio.2015.03.007

Pawlowska, T.E., Charvat, I. 2004. Heavy-metal stress and developmental patterns of arbuscular mycorrhizal fungi. Applied and Environmental Microbiology, 70, 6643-6649. doi:

\subsection{8/AEM.70.11.6643-6649.2004}

Peay, K.G., Bruns, T.D. 2014. Spore dispersal of basidiomycete fungi at the landscape scale is driven by stochastic and deterministic processes and generates variability in plant-fungal interactions. New Phytologist, 204, 180-191. doi: 10.1111/nph.12906

Pelosi, C., Pey, B., Hedde, M., Caro, G., Capowiez, Y., Guernion, M., Peignée, J., Pirond, D., Bertrandfg, M., Cluzeaud, D. 2014. Reducing tillage in cultivated fields increases earthworm functional diversity. Applied Soil Ecology, 83, 79-87. doi: 10.1016/j.apsoil.2013.10.005 
739 Qi, Y., Zhao, N., Liu, J., Huang, J. 2016. Biochemical responses of ten ectomycorrhizal fungal

740 isolates to manganese. Water, Air and Soil Pollution, 227, 477-487. doi: 10.1007/s11270-016-

$741 \quad 3183-6$

742 Rosas, A.L., Casadevall, A. 2001. Melanization decreases the susceptibility of Cryptococcus

743 neoformans to enzymatic degradation. Mycopathologia, 151, 53-56. doi:

$744 \quad$ 10.1023/A:1010977107089

745 Ruotsalanien, A.L., Markkola, A.M., Kozlov, M.V. 2009. Mycorrhizal colonisation of mountain 746 birch (Betula pubescens ssp. czerepanovii) along three environmental gradients: does life in 747 harsh environments alter plant-fungal relationships? Environmental Monitoring Assessment, 748 148, 215-232. doi: 10.1007/s10661-007-0152-y

749 Santorufo, L., Cortet, J., Nahmani, J., Pernin, C., Salmon, S., Pernot, A., Morel, J.L., Maisto, G.

750 2015. Responses of functional and taxonomic collembolan community structure to site

751 management in Mediterranean urban and surrounding areas. European Journal of Soil Biology,

752 70, 46-57. doi: 10.1016/j.ejsobi.2015.07.003

753 Schloss, P.D., Westcott, S.L., Ryabin, T., Hall, J.R., Hartmann, M., Hollister, E.B., ... Weber,

754 C.F. 2009. Introducing mothur: open-source, platform-independent, community-supported 755 software for describing and comparing microbial communities. Applied and Environmental 756 Microbiology, 75, 7537-41. doi: 10.1128/AEM.01541-09

757 Sousa, N.R., Ramos, M.A., Marques, A.P.G.C, Castro, P.M.L. 2014. A genotype dependent758 response to cadmium contamination in soil is displayed by Pinus pinaster in symbiosis with 759 different mycorrhizal fungi. Applied Soil Ecology, 76, 7-13. doi: 10.1016/j.apsoil.2013.12.005 
760 Staudenrausch, S., Kaldorf, M., Renker, C., Luis, P., Buscot, F. 2005. Diversity of the

761 ectomycorrhiza community at a uranium mining heap. Biology and Fertility of Soils, 41, 439_

762 446. doi:10.1007/s00374-005-0849-4

763 Suz, L.M., Barsoum, N., Benham, S., Dietrich, H.P., Fetzer, K.D., Fischer, R., García, P.,

764 Gehrman, J., Kristöfel, F., Manninger, M. et al. 2014. Environmental drivers of ectomycorrhizal

765 communities in Europe's temperate oak forests. Molecular Ecology, 23, 5628-5644. doi:

$766 \quad 10.1111 / \mathrm{mec} .12947$

767 Tedersoo, L., Naadel, T., Bahram, M., Pritsch, K., Buegger, F., Leal, M., Kõljalg, U., Põldmaa, 768 K. 2012. Enzymatic activities and stable isotope patterns of ectomycorrhizal fungi in relation to 769 phylogeny and exploration types in an afrotropical rain forest. New Phytologist, 195, 832-843. 770 doi: 10.1111/j.1469-8137.2012.04217.x

771 ter Braak, C.J.F., Schaffers, A.P. 2012. Co-Correspondence Analysis : A New Ordination

772 Method to Relate Two Community Compositions. Ecology, 85, 834-846. doi: 10.1890/03-0021

773 Treseder, K.K., Lennon, J.T. 2015. Fungal Traits That Drive Ecosystem Dynamics on Land.

774 Microbiology and Molecular Biology Reviews, 79, 243-262. doi: 10.1128/MMBR.00001-15

775 Tunlid, A., Floudas, D., Koide, R.T., Rineau, F. 2017. Soil organic matter decomposition

776 mechanisms in ectomycorrhizal fungi. In: Martin F, ed. Molecular Mycorrhizal Symbiosis.

777 Hoboken, NJ, USA: John Wiley \& Sons, Inc. doi: 10.1002/9781118951446.ch15, 257-275.

778 Twieg, B.D., Durall, D.M., Simard, S.W., Jones, M.D. 2009. Influence of soil nutrients on

779 ectomycorrhizal communities in a chronosequence of mixed temperate forests. Mycorrhiza, 19, $780 \quad 305-316$. doi: 10.1007/s00572-009-0232-7 
781 van der Heijden, M.G.A., Martin, F.M., Selosse, M.A., Sanders, I.R. 2015. Mycorrhizal ecology

782 and evolution: the past, the present, and the future. New Phytologist, 205, 1406-1423. doi:

$783 \quad 10.1111 /$ nph. 13288

784 Visser, S. 1995. Ectomycorrhizal fungal succession in jack pine stands following wildfire. New

785 Phytologist, 129, 389-401. doi:10.1111/j.1469-8137.1995.tb04309.x

786 Wallander, H., Johansson, U., Sterkenburg, E., Durling, M.B., Lindahl, B.D. 2010. Production of

787 ectomycorrhizal mycelium peaks during canopy closure in Norway spruce forests. New

788 Phytologist, 187, 1124-1134. doi:10.1111/j.1469-8137.2010.03324.x

789 White, T.J., Bruns, S., Lee, S., Taylor, J. 1990. Amplification and direct sequencing of fungal

790 ribosomal RNA genes for phylogenetics. In: Innis, M.A., Gelfand, D.H, Sninsky, J.J., White, T.J.

791 (Eds.), PCR Protocols: A Guide to Methods and Applications. Academic Press, London, pp. 315-

792322.

793 
794 Fig. 1. Principal component analysis (PCA) of soil variables and trace elements in four locations 795 across the Guadiamar river valley (SW Spain) which differ in exposure to contamination by trace 796 elements and inherent soil background variables.

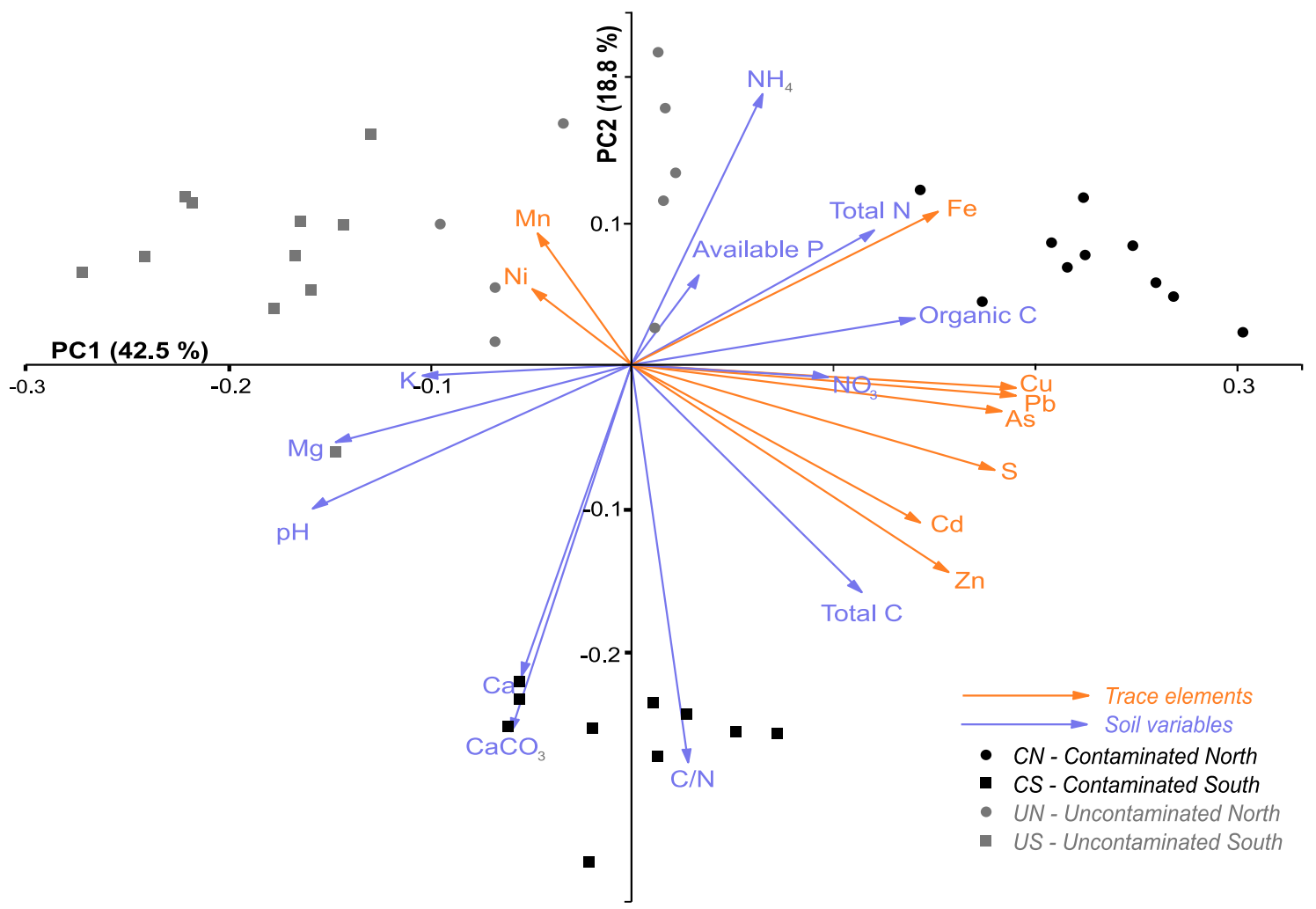

801 Fig. 2. Redundancy analysis triplots of ectomycorrhizal (ECM) fungal communities driven by trace element contamination and soil background variables in the Guadiamar river valley (SW

803 Spain). a) Species-based redundancy analysis (triplot) and variation partitioning analysis (pie 804 chart). Species present in less than 5\% have not been represented. b) Trait Community Weighted 805 Mean (CWM)-based redundancy analysis (triplot) and variation partitioning analysis (pie chart). 806 The mean frequency of emanating hyphae, rhizomorphs and melanization (as a function of the 807 black color component) of ECM fungal communities are included in the analysis. 
a) Species-based redundancy analysis (triplot) and variation partitioning analysis (pie chart)

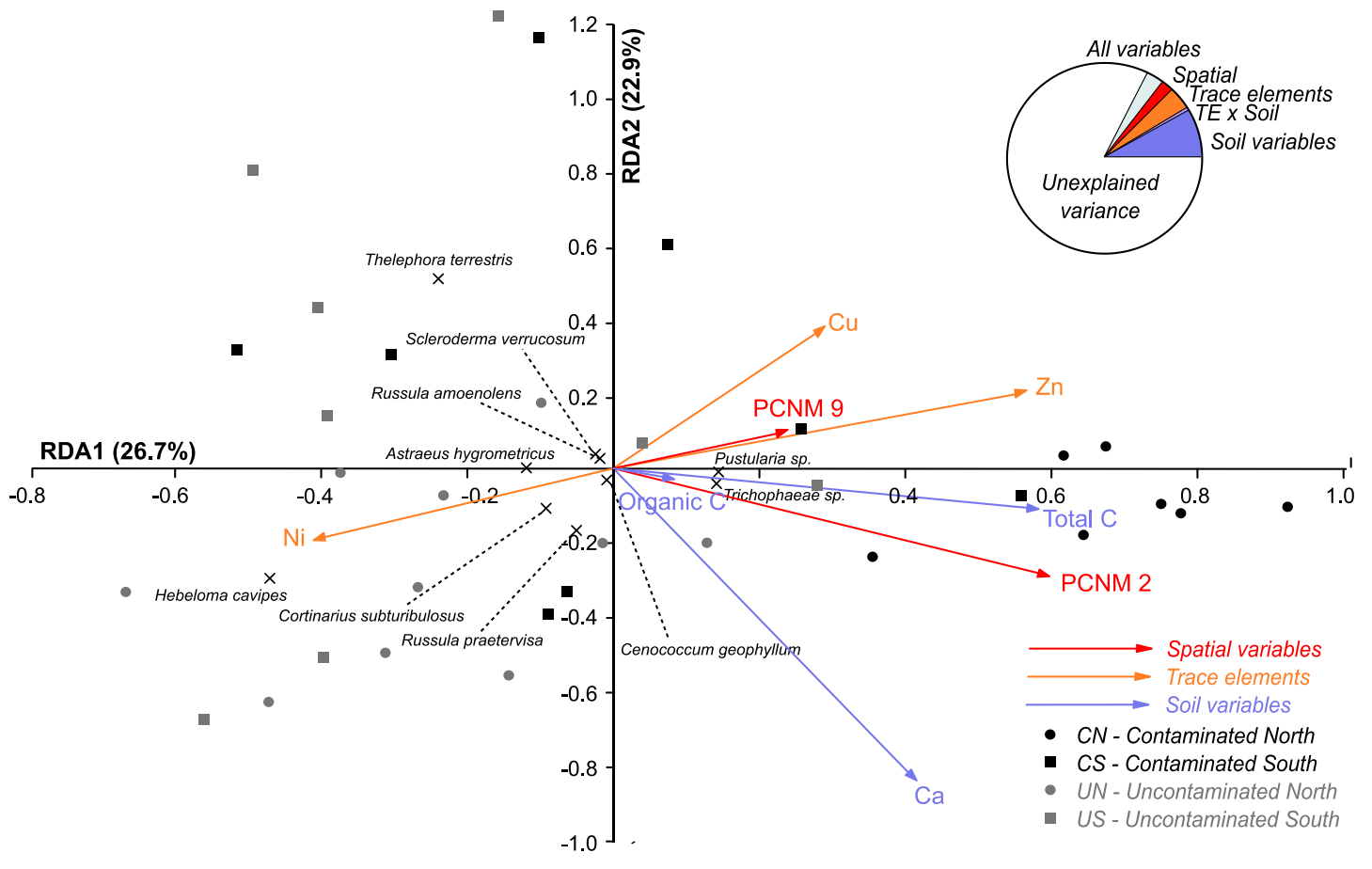

b) Trait Community Weighted Mean (CWM)-based redundancy analysis (triplot) and variation partitioning analysis (pie chart)

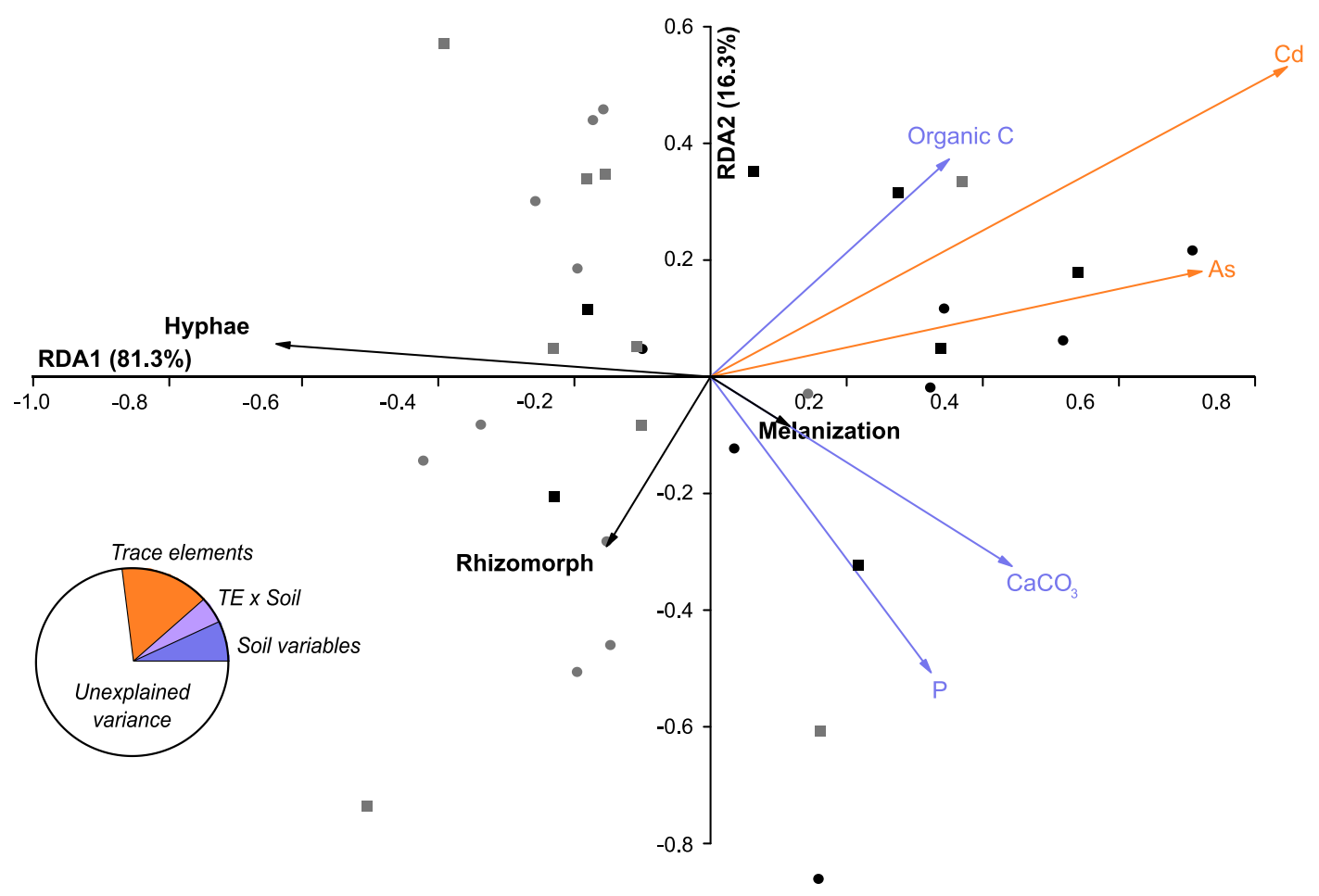


810 Table 1. Mean values of soil variables $( \pm \mathrm{SE})$ in the two studied plots affected and the two

811 unaffected by the toxic mine spill of Guadiamar river (SW Spain). Contaminated north (CN) and 812 south (CS), uncontaminated north (UN) and south (US). ANOVA analysis is displayed in last

813 two columns (F and $P$ ). Means not sharing a letter in common differ significantly according to

814 the Tukey's Honest post hoc.

\section{5}

\begin{tabular}{|c|c|c|c|c|c|c|}
\hline \multirow[b]{2}{*}{ Soil variables } & \multicolumn{2}{|c|}{ Contaminated plots } & \multicolumn{2}{|c|}{ Uncontaminated plots } & \multicolumn{2}{|c|}{ ANOVA } \\
\hline & $\mathrm{CN}$ & CS & UN & US & $\mathrm{F}$ & $P$ values \\
\hline $\mathrm{pH}$ & $4.84 \pm 0.23 c$ & $6.97 \pm 0.15 a$ & $6.26 \pm 0.13 b$ & $7.33 \pm 0.03 \mathbf{a}$ & 51.48 & $<0.001$ \\
\hline $\mathrm{Ca}\left(\mathrm{mg} \mathrm{kg}^{-1}\right)$ & $1,890 \pm 270 b$ & $4,890 \pm 90 \mathbf{a}$ & $2,190 \pm 520 b$ & $3,240 \pm 410 b$ & 13.39 & $<0.001$ \\
\hline $\mathrm{K}\left(\mathrm{mg} \mathrm{kg}^{-1}\right)$ & $139.16 \pm 18.33 b$ & $212.01 \pm 12.71 \mathrm{ab}$ & $286.11 \pm 27.93 \mathbf{a}$ & $235.92 \pm 18.39 a$ & 9.25 & $<0.001$ \\
\hline $\mathrm{Mg}\left(\mathrm{mg} \mathrm{kg}^{-1}\right)$ & $97.02 \pm 8.27 \mathrm{c}$ & $193.21 \pm 5.76 \mathbf{b}$ & $203.99 \pm 29.82 b$ & $289.54 \pm 29.20 \mathbf{a}$ & 15.68 & $<0.001$ \\
\hline$P\left(\mathrm{mg} \mathrm{kg}^{-1}\right)$ & $12.72 \pm 1.28$ & $8.12 \pm 0.88$ & $10.38 \pm 1.71$ & $17.17 \pm 4.75$ & 0.72 & 0.547 \\
\hline $\mathrm{CaCO}_{3}(\%)$ & $0.55 \pm 0.06 c$ & $8.13 \pm 0.38 a$ & $1.20 \pm 0.13 b$ & $1.41 \pm 0.24 b$ & 133.1 & $<0.001$ \\
\hline $\mathrm{NH}_{4}\left(\mathrm{mg} \mathrm{kg}^{-1}\right)$ & $4.77 \pm 0.34 a$ & $2.87 \pm 0.17 b$ & $5.07 \pm 0.57 a$ & $3.49 \pm 0.28 b$ & 10.55 & $<0.001$ \\
\hline $\mathrm{NO}_{3}\left(\mathrm{mg} \mathrm{kg}^{-1}\right)$ & $4.78 \pm 1.35 a$ & $2.49 \pm 0.45 a$ & $2.64 \pm 0.47 a$ & $1.21 \pm 0.19 b$ & 4.27 & 0.011 \\
\hline Total C (\%) & $1.72 \pm 0.16 b$ & $2.04 \pm 0.08 a$ & $1.56 \pm 0.13 b$ & $1.02 \pm 0.09 c$ & 11.93 & $<0.001$ \\
\hline Total N (\%) & $0.16 \pm 0.02 a$ & $0.11 \pm 0.00 b$ & $0.15 \pm 0.01 \mathrm{a}$ & $0.10 \pm 0.01 b$ & 10.65 & $<0.001$ \\
\hline
\end{tabular}

\begin{tabular}{|c|c|c|c|c|c|c|}
\hline \multicolumn{7}{|c|}{ Total Trace Element } \\
\hline As $\left(\mathrm{mg} \mathrm{kg}^{-1}\right)$ & $161.83 \pm 21.71 \mathrm{a}$ & $40.39 \pm 4.98 b$ & $18.03 \pm 1.27 c$ & $13.52 \pm 1.09 c$ & 97.26 & $<0.001$ \\
\hline $\mathrm{Cd}\left(\mathrm{mg} \mathrm{kg}^{-1}\right)$ & $0.68 \pm 0.11 a$ & $0.67 \pm 0.07 a$ & $0.21 \pm 0.03 b$ & $0.02 \pm 0.01 \mathrm{c}$ & 43.62 & $<0.001$ \\
\hline $\mathrm{Cu}\left(\mathrm{mg} \mathrm{kg}^{-1}\right)$ & $192.55 \pm 7.82 a$ & $58.15 \pm 5.70 b$ & $40.54 \pm 4.46 b$ & $18.69 \pm 1.72 c$ & 211 & $<0.001$ \\
\hline $\mathrm{Fe}\left(\mathrm{mg} \mathrm{g}^{-1}\right)$ & $40.48 \pm 2.14 a$ & $21.97 \pm 0.57 \mathrm{c}$ & $27.52 \pm 0.93 \mathrm{ab}$ & $22.80 \pm 1.50 \mathrm{bc}$ & 27.57 & $<0.001$ \\
\hline $\operatorname{Mn}\left(\mathrm{mg} \mathrm{kg}^{-1}\right)$ & $391.53 \pm 39.47 b$ & $414.78 \pm 15.41 b$ & $851.88 \pm 29.62 a$ & $486.40 \pm 47.77 b$ & 37.09 & $<0.001$ \\
\hline $\mathrm{Ni}\left(\mathrm{mg} \mathrm{kg}^{-1}\right)$ & $13.01 \pm 0.70 b$ & $14.60 \pm 0.44 b$ & $21.69 \pm 1.04 a$ & $15.73 \pm 1.23 b$ & 17.44 & $<0.001$ \\
\hline $\mathrm{Pb}\left(\mathrm{mg} \mathrm{kg}^{-1}\right)$ & $274.40 \pm 37.54 a$ & $76.66 \pm 8.26 b$ & $57.57 \pm 6.87 b$ & $19.82 \pm 1.14 c$ & 89.89 & $<0.001$ \\
\hline $\mathrm{S}\left(\mathrm{mg} \mathrm{g}^{-1}\right)$ & $3.12 \pm 0.41 a$ & $0.71 \pm 0.09 b$ & $0.17 \pm 0.02 c$ & $0.10 \pm 0.01 \mathrm{c}$ & 123.3 & $<0.001$ \\
\hline $\mathrm{Zn}\left(\mathrm{mg} \mathrm{kg}^{-1}\right)$ & $228.99 \pm 29.61 a$ & $229.65 \pm 21.54 a$ & $96.93 \pm 9.25 \mathbf{b}$ & $44.43 \pm 3.71 \mathrm{c}$ & 66.39 & $<0.001$ \\
\hline
\end{tabular}


817 Table 2. Results of the fourth corner analysis of the relationships between ectomycorrhizal

818 fungal traits and soil factors in the Guadiamar river valley (SW Spain). The $r$ values shown

819 indicate the strength of the interactions. Bold letter: $\mathrm{P}<0.10 ; *: P<0.05$.

\begin{tabular}{|c|c|c|c|}
\hline & Hyphae & Rhizomorph & Melanization \\
\hline As & $-0.30^{*}$ & -0.13 & 0.10 \\
\hline $\mathrm{Cd}$ & $-0.33^{*}$ & -0.27 & 0.08 \\
\hline $\mathrm{Cu}$ & -0.25 & -0.17 & -0.06 \\
\hline $\mathrm{Fe}$ & -0.08 & 0.00 & -0.26 \\
\hline $\mathrm{Mn}$ & 0.14 & 0.10 & -0.28 \\
\hline $\mathrm{Ni}$ & 0.14 & 0.17 & -0.27 \\
\hline $\mathrm{Pb}$ & -0.28 & -0.19 & -0.01 \\
\hline S & $-0.33^{*}$ & -0.16 & 0.09 \\
\hline $\mathrm{Zn}$ & $-0.35^{\star}$ & -0.16 & 0.12 \\
\hline $\mathrm{pH}$ & 0.06 & 0.12 & 0.25 \\
\hline $\mathrm{CaCO}_{3}$ & -0.19 & 0.00 & $0.41^{\star}$ \\
\hline K & 0.05 & 0.03 & 0.13 \\
\hline $\mathrm{Ca}$ & -0.13 & 0.12 & 0.31 \\
\hline $\mathrm{Mg}$ & 0.08 & 0.20 & 0.14 \\
\hline Total C & $-0.31^{*}$ & -0.14 & 0.14 \\
\hline Organic C & -0.14 & -0.12 & -0.12 \\
\hline $\mathrm{C} / \mathrm{N}$ & -0.13 & -0.14 & 0.02 \\
\hline Total N & -0.12 & -0.09 & -0.18 \\
\hline $\mathrm{NH}_{4}$ & 0.07 & 0.00 & -0.18 \\
\hline $\mathrm{NO}_{3}$ & -0.23 & -0.25 & 0.13 \\
\hline$P$ & -0.12 & 0.16 & -0.02 \\
\hline
\end{tabular}

820

821 
822 Table3. Pearson correlation coefficients between trait distribution of ectomycorrhizal fungal

823 communities, as standardized effect size of mean pairwise distances of communities for each

824 fungal trait, and trace element concentrations and soil variables in the Guadiamar river valley

825 (SW Spain). Only the selected soil variables in the best trait-based RDA model were included. *:

$826 \quad P<0.05$

\begin{tabular}{lccc}
\hline & $\begin{array}{c}\text { Emanating hyphae } \\
\text { (ses.mpd) }\end{array}$ & $\begin{array}{c}\text { Rhizomorph } \\
\text { (ses.mpd) }\end{array}$ & $\begin{array}{c}\text { Melanization } \\
\text { (ses.mpd) }\end{array}$ \\
\hline $\mathrm{As}$ & 0.183 & -0.250 & -0.420 \\
$\mathrm{Cd}$ & 0.427 & $\mathbf{- 0 . 4 8 2 ^ { * }}$ & -0.331 \\
$\mathrm{CaCO}_{3}$ & 0.104 & 0.111 & 0.095 \\
Organic C & 0.181 & -0.222 & -0.396 \\
Available P & 0.349 & 0.360 & 0.126 \\
\hline
\end{tabular}

827

828 
830 Figure S1 Map of the study area and location of plots.

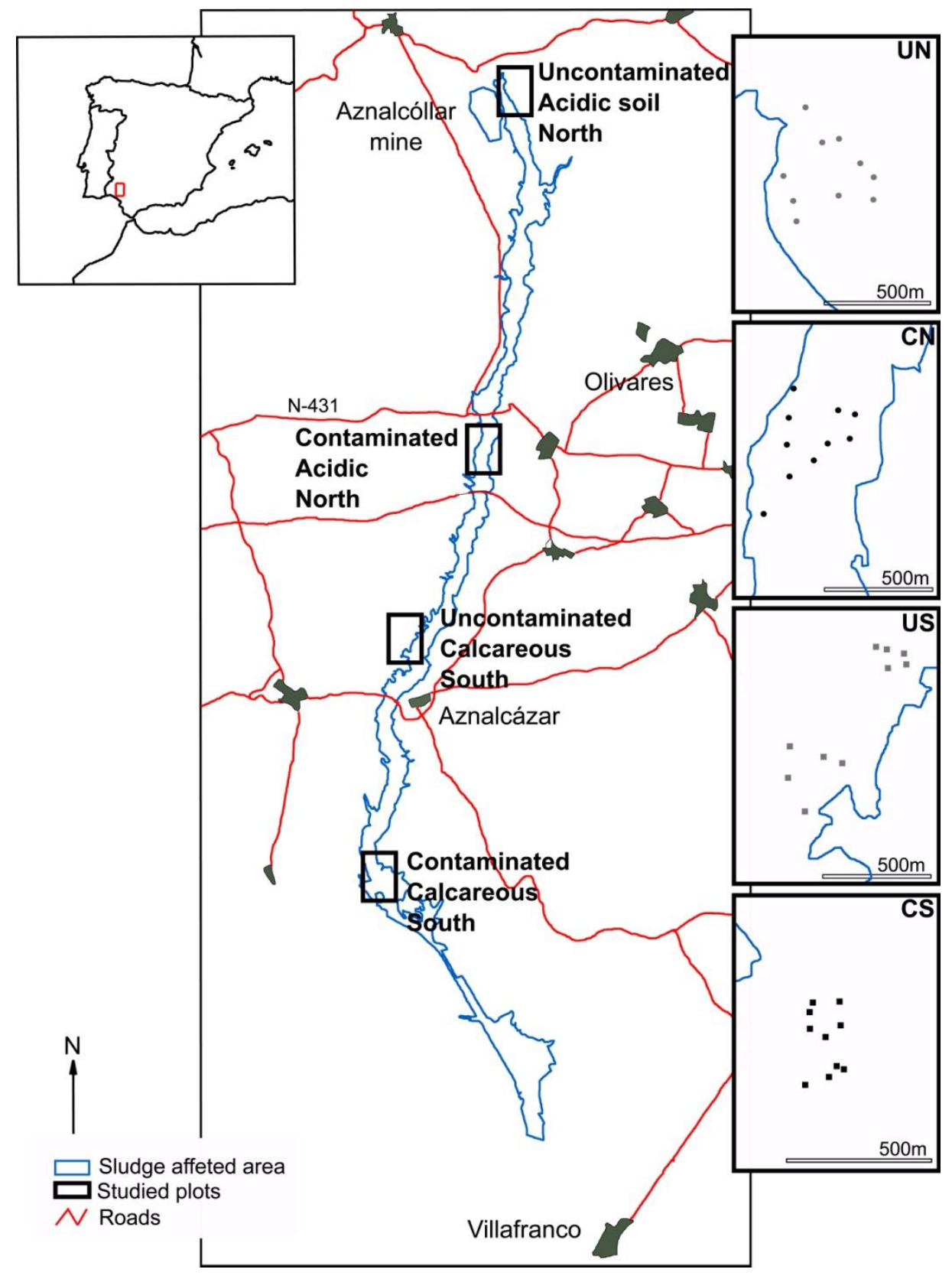




\section{Supporting Information}

834 Figure S2 Rarefaction analysis of OTU distribution in the analyzed ectomycorrhizal root tips from

835 Guadiamar river valley (SW Spain). Contaminated North (CN), Contaminated South (CS),

836 Uncontaminated North (UN), Uncontaminated South (US).

837

838

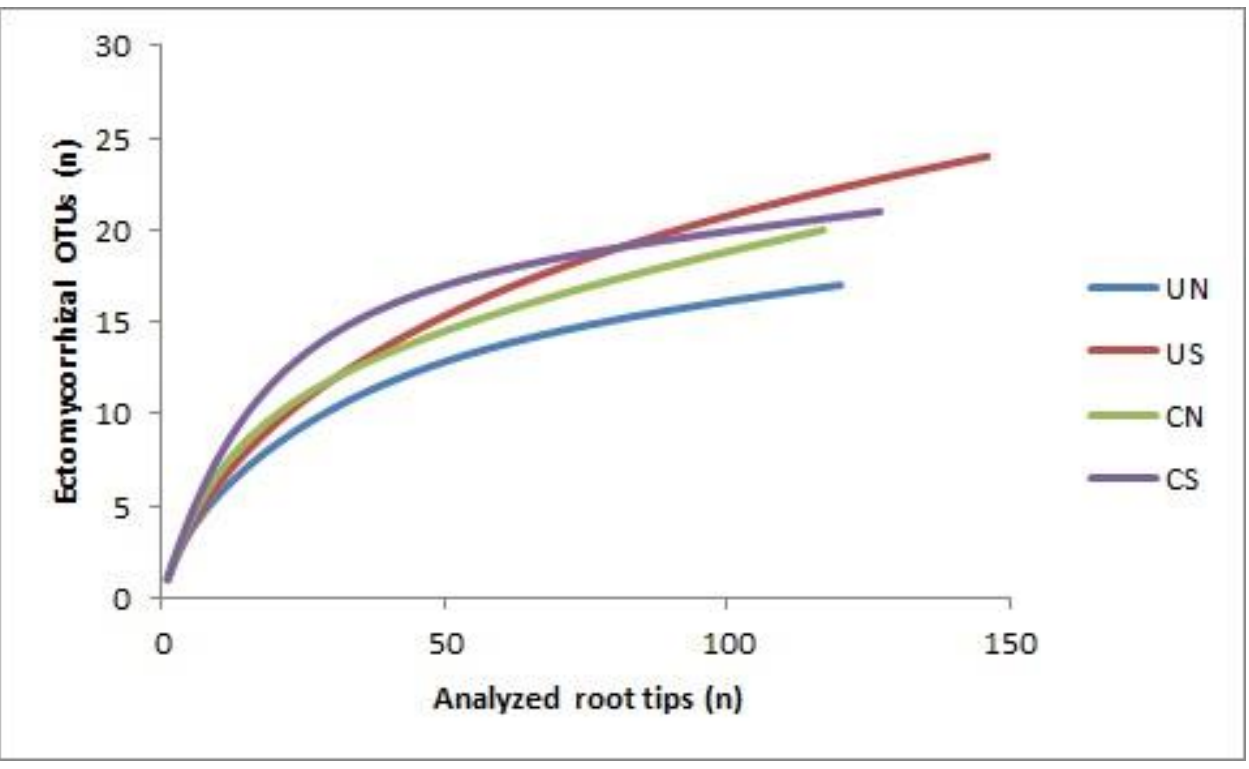

839

840 


\section{Supporting Information}

842 Table S1. Overall distribution of texture components in the sampled plots (data from Domínguez pers.

843 comm.) and soil type classification (according to Clemente et al. 2000) in the four sample sites in

844 Guadiamar river valley (SW Spain). Geographic locations of specific sampled trees. Contaminated north

845 (CN) and south (CS), uncontaminated north (UN) and south (US).

846

\begin{tabular}{|c|c|c|c|c|}
\hline & $\mathrm{CN}$ & CS & UN & US \\
\hline Coarse sand (\%) & 30.1 & 24.5 & 31.6 & 24.8 \\
\hline Fine sand (\%) & 21.6 & 15.2 & 16.2 & 27.2 \\
\hline Silt (\%) & 27.8 & 33.3 & 31.2 & 24.1 \\
\hline Clay (\%) & 20.4 & 27 & 21.1 & 22.7 \\
\hline Soil type & $\begin{array}{l}\text { Typic/Aquic } \\
\text { Xerofluvent }\end{array}$ & Aquic Haploxeralf & Typic Xerofluvent & $\begin{array}{l}\text { Typic Rhodoxeralf/ } \\
\text { Typic Haploxeralf }\end{array}$ \\
\hline \multicolumn{5}{|c|}{ UTM coordinates of sampled trees } \\
\hline & $37.386733,-6.226050$ & $37.242796,-6.262997$ & $37.501699,-6.223200$ & $37.326128,-6.254079$ \\
\hline & $37.385683,-6.226283$ & $37.242426,-6.263540$ & $37.500837,-6.222986$ & $37.326017,-6.253461$ \\
\hline & $37.384788,-6.228140$ & $37.243197,-6.264157$ & $37.501934,-6.220785$ & $37.325835,-6.252575$ \\
\hline & $37.385500,-6.227400$ & $37.242692,-6.264152$ & $37.501747,-6.218971$ & $37.325364,-6.252395$ \\
\hline & $37.387800,-6.229283$ & $37.241216,-6.263381$ & $37.502676,-6.218921$ & $37.321194,-6.255822$ \\
\hline & $37.386588,-6.229400$ & $37.240979,-6.264334$ & $37.503267,-6.219647$ & $37.321470,-6.256862$ \\
\hline & $37.385405,-6.229497$ & $37.241460,-6.262851$ & $37.504298,-6.220750$ & $37.321916,-6.258642$ \\
\hline & $37.384155,-6.229326$ & $37.241546,-6.263120$ & $37.504149,-6.221652$ & $37.320483,-6.258804$ \\
\hline & $37.382667,-6.229817$ & $37.243488,-6.264055$ & $37.505631,-6.222518$ & $37.319079,-6.257846$ \\
\hline
\end{tabular}

848 Reference

849 Clemente, L., Cabrera, F., García, L.V., Cara, J.S. 2000. Reconocimiento de suelos y estudio de su

850 contaminación por metales pesados en el valle del Guadiamar. Edafología, 7-3, 337-349. 


\section{Supporting Information}

853 Table S2. Species list found in the study (Guadiamar river valley, SW Spain). Number of root tips

854 identified in each plot (Contaminated North - CN, Contaminated South - CS, Uncontaminated North 855 UN, Uncontaminated South - US). Number of trees in which they were detected (Occurence). Blast

856 results against the UNITE database and Species Hypothesis (SH) (only matches higher than $97 \%$ are 857 shown).

858 


\begin{tabular}{|c|c|c|c|c|c|c|c|c|c|c|}
\hline Phylum & Family & Species & $\mathrm{CN}$ & CS & UN & US & Occurrence & Closest match (Acc. No.) & $\begin{array}{l}\text { Identity } \\
\text { (\%) }\end{array}$ & $\begin{array}{l}\text { Species Hypothesis } \\
\text { (UNITE) }\end{array}$ \\
\hline \multicolumn{11}{|c|}{ Ascomycota } \\
\hline & Gloniaceae & $\begin{array}{l}\text { Cenococcum } \\
\text { geophyllum }\end{array}$ & & & 4 & 10 & 3 & $\begin{array}{l}\text { Uncultured ectomycorrhiza (Cenococcum } \\
\text { geophilum) (AY299214) }\end{array}$ & 99 & $\underline{\mathrm{SH} 214459.07 \mathrm{FU}}$ \\
\hline & Pyronemataceae & Geopora cervina & & 9 & & & 2 & Uncultured Geopora (GU327416) & 99 & $\underline{\mathrm{SH} 213655.07 \mathrm{FU}}$ \\
\hline & Pyronemataceae & Geopora sp. & & 1 & & & 1 & Geopora sp. (UDB011007) & 97 & $\underline{\mathrm{SH} 213666.07 \mathrm{FU}}$ \\
\hline & Pezizaceae & Peziza michelii & & 5 & & 1 & 3 & Peziza michelii (JF908553) & 98 & $\underline{\mathrm{SH} 218195.07 \mathrm{FU}}$ \\
\hline & Pezizaceae & Peziza sp. & 1 & & & & 1 & Peziza sp. (KP311474) & 99 & $\underline{\mathrm{SH} 189857.07 \mathrm{FU}}$ \\
\hline & Pyronemataceae & Pustularia sp. & 3 & 8 & & 2 & 4 & Uncultured Ascomycete (EU557319) & 99 & $\underline{\mathrm{SH} 222141.07 \mathrm{FU}}$ \\
\hline & Pyronemataceae & $\begin{array}{l}\text { Pyronemataceae } \\
\text { sp. } 1\end{array}$ & & & 1 & & 1 & Uncultured fungus (JF927116) & 93 & $\underline{\mathrm{SH} 213666.07 \mathrm{FU}}$ \\
\hline & Pyronemataceae & $\begin{array}{l}\text { Pyronemataceae } \\
\text { sp. } 2\end{array}$ & & 4 & & & 1 & Uncultured fungus (KM247654) & 99 & - \\
\hline & Pyronemataceae & $\begin{array}{l}\text { Pyronemataceae } \\
\text { sp. } 3\end{array}$ & & & & 4 & 1 & $\begin{array}{l}\text { Uncultured ectomycorrhizal fungus } \\
\text { (FJ008039) }\end{array}$ & 99 & $\underline{\text { SH025866.07FU }}$ \\
\hline & Pyronemataceae & Trichophaeae sp. & 2 & 7 & & 4 & 5 & Uncultured Pyronemataceae sp. (HM370456) & 97 & $\underline{\mathrm{SH} 215396.07 \mathrm{FU}}$ \\
\hline & Tuberaceae & $\begin{array}{l}\text { Tuber } \\
\text { oligospermum }\end{array}$ & & & & 1 & 1 & Tuber oligospermum (FM205504) & 97 & $\underline{\mathrm{SH} 188863.07 \mathrm{FU}}$ \\
\hline & Tuberaceae & Tuber sp. 1 & & 1 & & & 2 & Tuber sp. (KC517481) & 95 & - \\
\hline & Tuberaceae & Tuber sp. 2 & & 3 & & & 1 & Uncultured Tuber (HQ204754) & 96 & - \\
\hline & Tuberaceae & Tuberaceae sp. 1 & 1 & & 7 & & 1 & $\begin{array}{l}\text { Uncultured ectomycorrhizal fungus } \\
\text { (HM057200) }\end{array}$ & 92 & $\underline{\mathrm{SH} 185378.07 \mathrm{FU}}$ \\
\hline \multicolumn{11}{|c|}{ Basidiomycota } \\
\hline & Diplocystidiaceae & $\begin{array}{l}\text { Astraeus } \\
\text { hygrometricus }\end{array}$ & 3 & & 5 & 1 & 4 & Astraeus hygrometricus (HG000293) & 99 & $\underline{\mathrm{SH} 190454.07 \mathrm{FU}}$ \\
\hline & Cortinariaceae & Cortinarius belleri & & & 5 & & 2 & Cortinarius belleri (AY669685) & 99 & $\underline{\mathrm{SH} 188471.07 \mathrm{FU}}$ \\
\hline & Cortinariaceae & $\begin{array}{l}\text { Cortinarius } \\
\text { subbalaustinus }\end{array}$ & & & & 6 & 3 & Uncultured Cortinarius (GU246986) & 99 & $\underline{\mathrm{SH} 188517.07 \mathrm{FU}}$ \\
\hline Phylum & Family & Species & CN & CS & UN & US & Occurrence & Closest match (Acc. No.) & $\begin{array}{c}\text { Identity } \\
\text { (\%) }\end{array}$ & $\begin{array}{l}\text { Species Hypothesis } \\
\text { (UNITE) }\end{array}$ \\
\hline & Cortinariaceae & Cortinarius & & & 3 & 24 & 5 & Uncultured mycorrhizal fungus (FJ897182) & 100 & $\underline{\mathrm{SH} 188545.07 \mathrm{FU}}$ \\
\hline
\end{tabular}


This is the accepted version of the published article available at https://doi.org/10.1016/j.soilbio.2018.03.021

\begin{tabular}{|c|c|c|c|c|c|c|c|c|c|c|}
\hline & & subturibulosus & & & & & & & & \\
\hline & Entolomataceae & $\begin{array}{l}\text { Entoloma } \\
\text { inusitatum }\end{array}$ & 7 & & & & 3 & Uncultured Entolomaceae (FJ210729) & 99 & $\underline{\mathrm{SH} 181020.07 \mathrm{FU}}$ \\
\hline & Cortinariaceae & Hebeloma cavipes & 10 & & 26 & 45 & 19 & Hebeloma cavipes (KT225477) & 100 & $\underline{\mathrm{SH} 215994.07 \mathrm{FU}}$ \\
\hline & Cortinariaceae & $\begin{array}{l}\text { Hebeloma } \\
\text { cistophilum }\end{array}$ & & & & 3 & 1 & Uncultured fungus clone (HQ625447) & 99 & $\underline{\mathrm{SH} 218875.07 \mathrm{FU}}$ \\
\hline & Strophariaceae & $\begin{array}{l}\text { Hymenogaster } \\
\text { griseus }\end{array}$ & & 1 & & & 1 & Hymenogaster griseus (AF325636) & 99 & $\underline{\mathrm{SH} 218859.07 \mathrm{FU}}$ \\
\hline & Inocybaceae & Inocybe curvipes & 1 & & 3 & & 3 & Inocybe cf. curvipes (KT275613) & 97 & $\underline{\mathrm{SH} 201231.07 \mathrm{FU}}$ \\
\hline & Inocybaceae & $\begin{array}{l}\text { Inocybe } \\
\text { griseovelata }\end{array}$ & & 6 & & & 2 & Inocybe griseovelata (JF908237) & 97 & $\underline{\mathrm{SH} 176687.07 \mathrm{FU}}$ \\
\hline & Inocybaceae & Inocybe jacobi & 1 & & & & 1 & Inocybe jacobi (HQ604812) & 99 & $\underline{\mathrm{SH} 211892.07 \mathrm{FU}}$ \\
\hline & Inocybaceae & $\begin{array}{l}\text { Inocybe } \\
\text { praetervisa }\end{array}$ & & & & 1 & 1 & Inocybe sp. (KM576438) & 98 & $\underline{\mathrm{SH} 212066.07 \mathrm{FU}}$ \\
\hline & Inocybaceae & Inocybe squamata & & & & 1 & 1 & Inocybe squamata (FJ904136) & 99 & $\underline{\mathrm{SH} 222043.07 \mathrm{FU}}$ \\
\hline & Hydnangiaceae & Laccaria laccata & 4 & & 3 & & 3 & Laccaria laccata (KM067883) & 100 & $\underline{\mathrm{SH} 220959.07 \mathrm{FU}}$ \\
\hline & Russulaceae & Lactarius sp. 1 & 1 & & & & 1 & Lactarius atlanticus (KR025612) & 96 & - \\
\hline & Russulaceae & Lactarius sp. 2 & 1 & & & & 1 & Lactarius atlanticus (KP420216) & 95 & - \\
\hline & Paxillaceae & $\begin{array}{l}\text { Melanogaster } \\
\text { vittadinii }\end{array}$ & & & & 1 & 1 & Melanogaster vittadinii (AJ555525) & 97 & $\underline{\mathrm{SH} 182656.07 \mathrm{FU}}$ \\
\hline & Sclerodermataceae & Pisolithus arhizus & & & 1 & & 1 & Pisolithus arhizus (FR748128) & 98 & $\underline{\mathrm{SH} 177625.07 \mathrm{FU}}$ \\
\hline & Sclerodermataceae & $\begin{array}{l}\text { Pisolithus } \\
\text { tinctorius }\end{array}$ & & & 5 & 3 & 2 & Pisolithus tinctorius (HE578142) & 99 & $\underline{\mathrm{SH} 177623.07 \mathrm{FU}}$ \\
\hline & Russulaceae & $\begin{array}{l}\text { Russula } \\
\text { amoenolens }\end{array}$ & 19 & & 1 & 2 & 5 & Russulaceae (KT334781) & 99 & $\underline{\mathrm{SH} 220816.07 \mathrm{FU}}$ \\
\hline & Russulaceae & Russula ilicis & & & 9 & & 1 & Uncultured Russulaceae (HQ330996) & 99 & $\underline{\mathrm{SH} 180269.07 \mathrm{FU}}$ \\
\hline & Russulaceae & Russula insignis & & 9 & & & 3 & Russula insignis (AY061700) & 98 & $\underline{\mathrm{SH} 220848.07 \mathrm{FU}}$ \\
\hline & Russulaceae & $\begin{array}{l}\text { Russula } \\
\text { praetervisa }\end{array}$ & 10 & 5 & 2 & 16 & 5 & Uncultured Russula (FR852096) & 97 & $\underline{\mathrm{SH} 202443.07 \mathrm{FU}}$ \\
\hline Phylum & Family & Species & CN & CS & UN & US & Occurrence & Closest match (Acc. No.) & $\begin{array}{l}\text { Identity } \\
\text { (\%) }\end{array}$ & $\begin{array}{l}\text { Species Hypothesis } \\
\text { (UNITE) }\end{array}$ \\
\hline
\end{tabular}


This is the accepted version of the published article available at https://doi.org/10.1016/j.soilbio.2018.03.021

\begin{tabular}{|c|c|c|c|c|c|c|c|c|c|}
\hline Russulaceae & Russula sp. & & & & 1 & 1 & Uncultured Russula (KT334781) & 95 & - \\
\hline Sclerodermataceae & Scleroderma cepa & 4 & & & & 1 & Scleroderma laeve (KP004932) & 99 & $\underline{\mathrm{SH} 182463.07 \mathrm{FU}}$ \\
\hline Sclerodermataceae & $\begin{array}{l}\text { Scleroderma } \\
\text { meridionale }\end{array}$ & & & 1 & & 1 & Scleroderma meridionale (HF933239) & 100 & $\underline{\mathrm{SH} 186878.07 \mathrm{FU}}$ \\
\hline Sclerodermataceae & Scleroderma sp. 1 & & & 1 & & 1 & Uncultured fungus (FM999606) & 95 & SH179758.07FU \\
\hline Sclerodermataceae & $\begin{array}{l}\text { Scleroderma } \\
\text { verrucosum }\end{array}$ & 13 & 3 & & 1 & 6 & Uncultured fungus (KM247623) & 99 & $\underline{\mathrm{SH} 182460.07 \mathrm{FU}}$ \\
\hline Thelephoraceae & $\begin{array}{l}\text { Thelephora } \\
\text { terrestris }\end{array}$ & 14 & & 42 & 5 & 12 & Uncultured Thelephora terrestris (KF007266) & 99 & $\underline{\mathrm{SH} 184510.07 \mathrm{FU}}$ \\
\hline Thelephoraceae & $\begin{array}{l}\text { Tomentella } \\
\text { castanea }\end{array}$ & 20 & & & & 1 & Tomentella cf. sublilacina (KU376404) & 100 & $\underline{\mathrm{SH} 184517.07 \mathrm{FU}}$ \\
\hline Thelephoraceae & $\begin{array}{l}\text { Tomentella } \\
\text { ferruginea }\end{array}$ & & 8 & & & 1 & Uncultured fungus clone (KM247776) & 99 & $\underline{\mathrm{SH} 184518.07 \mathrm{FU}}$ \\
\hline Thelephoraceae & $\begin{array}{l}\text { Tomentella } \\
\text { lilacinogrisea }\end{array}$ & & & & 3 & 1 & Uncultured fungus clone (KF297246) & 99 & $\underline{\mathrm{SH} 178628.07 \mathrm{FU}}$ \\
\hline Thelephoraceae & Tomentella sp. 1 & & 1 & & & 1 & Uncultured fungus clone (KM247736) & 99 & - \\
\hline Thelephoraceae & Tomentella sp. 10 & & 1 & & & 1 & Uncultured Tomentella (FJ197002) & 96 & - \\
\hline Thelephoraceae & Tomentella sp. 2 & & & & 7 & 1 & Uncultured fungus clone (KM247732) & 99 & SH177905.07FU \\
\hline Thelephoraceae & Tomentella sp. 3 & & & & 1 & 1 & Uncultured Tomentella (FJ210771) & 99 & $\underline{\mathrm{SH} 184642.07 \mathrm{FU}}$ \\
\hline Thelephoraceae & Tomentella sp. 4 & & 4 & & & 1 & Uncultured Tomentella (JX630358) & 97 & SH184626.07FU \\
\hline Thelephoraceae & Tomentella sp. 5 & & 10 & & & 1 & Uncultured Tomentella (LC013836) & 98 & - \\
\hline Thelephoraceae & Tomentella sp. 6 & 1 & 15 & & & 3 & Uncultured fungus (FN397409) & 99 & $\underline{\mathrm{SH} 177879.07 \mathrm{FU}}$ \\
\hline Thelephoraceae & Tomentella sp. 8 & 1 & 13 & & & 2 & Uncultured Tomentella (FR852207) & 99 & $\underline{\mathrm{SH} 002639.07 \mathrm{FU}}$ \\
\hline Thelephoraceae & Tomentella sp. 9 & & & & 1 & 1 & Uncultured Tomentella (KC840637) & 99 & SH177797.07FU \\
\hline
\end{tabular}

860

861 


\section{Supporting Information}

Table S3. Fungal trait measurements in the current study (Guadiamar river valley, SW Spain) and comparison with records of Deemy database (http://www.deemy.de). The experimental observations are expressed in term of frequency (percentage) of number of root tips exhibiting either emanating hyphae or rhizomorphs, and the black color content (0-100) of root tips for melanization. The records of species in this study are compared with the records of the same species in Deemy database (01-102017) when available (marked with asterisk). When the species was not recorded in Deemy, records from species of the same genera were displayed. The percentage of records showing different the different categories was shown. NA: absence of data; Distance Exploration types: Contact, Short, Medium mat, Medium fringe and Medium smooth (Agerer 2001, 2006); Emanating hyphae and rhizomorphs: Absent, Infrequent and Abundant. The $\mathrm{n}$ column is the number of root tips found for each species. 
This is the accepted version of the published article available at https://doi.org/10.1016/j.soilbio.2018.03.021

\begin{tabular}{|c|c|c|c|c|c|c|c|c|c|}
\hline \multirow[b]{2}{*}{ Phylum } & \multirow[b]{2}{*}{ Family } & \multirow[b]{2}{*}{ Species } & \multirow[b]{2}{*}{$\mathbf{n}$} & \multicolumn{3}{|c|}{ Experimental observations } & \multicolumn{3}{|c|}{ Deemy database } \\
\hline & & & & $\begin{array}{l}\text { Emanating } \\
\text { hyphae }\end{array}$ & Rhizomorphs & $\begin{array}{l}\text { Melanizatio } \\
\mathrm{n}\end{array}$ & Exploration type & Emanating hyphae & $\begin{array}{l}\text { Rhizomorph } \\
\text { presence }\end{array}$ \\
\hline \multicolumn{10}{|c|}{ Ascomycota } \\
\hline & Gloniaceae & $\begin{array}{l}\text { Cenococcum } \\
\text { geophyllum* }\end{array}$ & 14 & 100 & 0 & 90.5 & Short & Abundant & Absent \\
\hline & Pyronemataceae & Geopora cervina & 9 & 11.1 & 22.2 & 81.1 & NA & NA & NA \\
\hline & Pyronemataceae & Geopora sp. & 1 & 100 & 0 & 84 & NA & NA & NA \\
\hline & Pezizaceae & Peziza michelii & 6 & 33.3 & 16.7 & 82.1 & NA & NA & NA \\
\hline & Pezizaceae & Peziza sp. & 1 & 0 & 0 & 87.7 & NA & NA & NA \\
\hline & Pyronemataceae & Pustularia sp. & 13 & 53.8 & 0 & 76.2 & NA & NA & NA \\
\hline & Pyronemataceae & $\begin{array}{l}\text { Pyronemataceae } \\
\text { sp. } 1\end{array}$ & 1 & 0 & 0 & 80.3 & NA & NA & NA \\
\hline & Pyronemataceae & $\begin{array}{l}\text { Pyronemataceae } \\
\text { sp. } 2\end{array}$ & 4 & 75 & 0 & 85.7 & NA & NA & NA \\
\hline & Pyronemataceae & $\begin{array}{l}\text { Pyronemataceae } \\
\text { sp. } 3\end{array}$ & 4 & 75 & 0 & 87.6 & NA & NA & NA \\
\hline & Pyronemataceae & Trichophaeae sp. & 13 & 84.6 & 7.7 & 83.2 & NA & NA & NA \\
\hline & Tuberaceae & $\begin{array}{l}\text { Tuber } \\
\text { oligospermum }\end{array}$ & 1 & 100 & 100 & 84.7 & Short & $\begin{array}{c}\text { Abundant 26.1/ } \\
\text { Infrequent 52.2/ Absent } \\
21.7\end{array}$ & $\begin{array}{c}\text { Infrequent 4.4/ } \\
\text { Absent } 95.6\end{array}$ \\
\hline & Tuberaceae & Tuber sp. 1 & 1 & 100 & 0 & 64 & Short & $\begin{array}{c}\text { Abundant 26.1/ } \\
\text { Infrequent 52.2/ Absent } \\
21.7\end{array}$ & $\begin{array}{c}\text { Infrequent 4.4/ } \\
\text { Absent } 95.6\end{array}$ \\
\hline
\end{tabular}


This is the accepted version of the published article available at https://doi.org/10.1016/j.soilbio.2018.03.021

\begin{tabular}{|c|c|c|c|c|c|c|c|c|c|}
\hline \multirow[b]{2}{*}{ Phylum } & \multirow[b]{2}{*}{ Family } & \multirow[b]{2}{*}{ Species } & \multirow[b]{2}{*}{$\mathbf{n}$} & \multicolumn{3}{|c|}{ Experimental observations } & \multicolumn{3}{|c|}{ Deemy database } \\
\hline & & & & $\begin{array}{l}\text { Emanating } \\
\text { hyphae }\end{array}$ & Rhizomorphs & Melanization & Exploration type & Emanating hyphae & $\begin{array}{l}\text { Rhizomorph } \\
\text { presence }\end{array}$ \\
\hline & Tuberaceae & Tuber sp. 2 & 3 & 0 & 0 & 84.7 & Short & $\begin{array}{c}\text { Abundant 26.1/ } \\
\text { Infrequent 52.2/ } \\
\text { Absent } 21.7\end{array}$ & $\begin{array}{c}\text { Infrequent 4.4/ } \\
\text { Absent } 95.6\end{array}$ \\
\hline & Tuberaceae & Tuberaceae sp. 1 & 8 & 12.5 & 0 & 77 & NA & NA & NA \\
\hline \multicolumn{10}{|c|}{ Basidiomycota } \\
\hline & Diplocystidiaceae & $\begin{array}{l}\text { Astraeus } \\
\text { hygrometricus }\end{array}$ & 9 & 44.4 & 44.4 & 79.3 & NA & NA & NA \\
\hline & Cortinariaceae & $\begin{array}{l}\text { Cortinarius } \\
\text { belleri* }^{*}\end{array}$ & 5 & 100 & 0 & 64.6 & $\begin{array}{c}\text { Medium fringe } \\
\text { 96.2/ Medium mat } \\
3.8\end{array}$ & $\begin{array}{l}\text { Abundant 65.4/ } \\
\text { Infrequent } 19.2\end{array}$ & $\begin{array}{l}\text { Abundant } \\
80.8 / \\
\text { Infrequent } \\
11.5\end{array}$ \\
\hline & Cortinariaceae & $\begin{array}{l}\text { Cortinarius } \\
\text { subbalaustinus* }\end{array}$ & 6 & 66.6 & 66.6 & 64.8 & $\begin{array}{c}\text { Medium fringe } \\
\text { 96.2/ Medium mat } \\
3.8\end{array}$ & $\begin{array}{l}\text { Abundant } 65.4 \text { / } \\
\text { Infrequent } 19.2\end{array}$ & $\begin{array}{l}\text { Abundant } \\
80.8 / \\
\text { Infrequent } \\
11.5\end{array}$ \\
\hline & Cortinariaceae & $\begin{array}{l}\text { Cortinarius } \\
\text { subturibulosus* }\end{array}$ & 27 & 96.3 & 25.9 & 72.9 & $\begin{array}{c}\text { Medium fringe } \\
\text { 96.2/ Medium mat } \\
3.8\end{array}$ & $\begin{array}{l}\text { Abundant 65.4/ } \\
\text { Infrequent } 19.2\end{array}$ & $\begin{array}{c}\text { Abundant } \\
80.8 / \\
\text { Infrequent } \\
11.5\end{array}$ \\
\hline & Entolomataceae & $\begin{array}{l}\text { Entoloma } \\
\text { inusitatum* }\end{array}$ & 7 & 42.9 & 0 & 68 & Medium smooth & $\begin{array}{c}\text { Abundant 33.3/ } \\
\text { Infrequent 33.3/ } \\
\text { Absent } 33.3\end{array}$ & $\begin{array}{l}\text { Abundant 33/ } \\
\text { Infrequent } 66\end{array}$ \\
\hline & Cortinariaceae & Hebeloma cavipes & 81 & 95.1 & 13.6 & 67.7 & $\begin{array}{c}\text { Short 87.5/ } \\
\text { Medium 12.5 }\end{array}$ & Abundant & $\begin{array}{c}\text { Abundant } \\
\text { 12.5/ Absent } \\
87.5\end{array}$ \\
\hline & Cortinariaceae & $\begin{array}{l}\text { Hebeloma } \\
\text { cistophilum }\end{array}$ & 3 & 100 & 0 & 69.7 & $\begin{array}{c}\text { Short 87.5/ } \\
\text { Medium } 12.5\end{array}$ & Abundant & $\begin{array}{c}\text { Abundant } \\
\text { 12.5/ Absent } \\
87.5\end{array}$ \\
\hline & Strophariaceae & $\begin{array}{l}\text { Hymenogaster } \\
\text { griseus }\end{array}$ & 1 & 100 & 0 & 77.3 & NA & NA & NA \\
\hline & Inocybaceae & Inocybe curvipes & 4 & 50 & 0 & 64.1 & Short & $\begin{array}{l}\text { Abundant } 40 / \\
\text { Infrequent } 60\end{array}$ & Absent \\
\hline & Inocybaceae & $\begin{array}{l}\text { Inocybe } \\
\text { griseovelata }\end{array}$ & 6 & 66.7 & 0 & 71 & Short & $\begin{array}{l}\text { Abundant } 40 / \\
\text { Infrequent } 60\end{array}$ & Absent \\
\hline & Inocybaceae & Inocybe jacobi & 1 & 100 & 0 & 76 & Short & $\begin{array}{l}\text { Abundant } 40 / \\
\text { Infrequent } 60\end{array}$ & Absent \\
\hline
\end{tabular}


This is the accepted version of the published article available at https://doi.org/10.1016/j.soilbio.2018.03.021

\begin{tabular}{|c|c|c|c|c|c|c|c|c|c|}
\hline \multirow[b]{2}{*}{ Phylum } & \multirow[b]{2}{*}{ Family } & \multirow[b]{2}{*}{ Species } & \multirow[b]{2}{*}{$\mathrm{n}$} & \multicolumn{3}{|c|}{ Experimental observations } & \multicolumn{3}{|c|}{ Deemy database } \\
\hline & & & & $\begin{array}{l}\text { Emanating } \\
\text { hyphae }\end{array}$ & Rhizomorphs & Melanization & Exploration type & Emanating hyphae & $\begin{array}{l}\text { Rhizomorph } \\
\text { presence }\end{array}$ \\
\hline & Inocybaceae & $\begin{array}{l}\text { Inocybe } \\
\text { praetervisa }\end{array}$ & 1 & 100 & 0 & 93.3 & Short & $\begin{array}{l}\text { Abundant } 40 / \\
\text { Infrequent } 60\end{array}$ & Absent \\
\hline & Inocybaceae & Inocybe squamata & 1 & 100 & 0 & 70.7 & Short & $\begin{array}{l}\text { Abundant40/ } \\
\text { Infrequent } 60\end{array}$ & Absent \\
\hline & Hydnangiaceae & Laccaria laccata & 7 & 71.4 & 14.3 & 71.4 & Medium smooth & $\begin{array}{l}\text { Abundant 87.5/ } \\
\text { Infrequent } 62.5\end{array}$ & $\begin{array}{c}\text { Abundant } \\
\text { 12.4/ } \\
\text { Infrequent } \\
\text { 37.5/ Absent } \\
62.5\end{array}$ \\
\hline & Russulaceae & Lactarius sp. 1 & 1 & 0 & 0 & 79 & $\begin{array}{c}\text { Contact 35.7/ } \\
\text { Medium smooth } \\
64.3\end{array}$ & $\begin{array}{c}\text { Absent 56.4/ } \\
\text { Infrequent } 48.7\end{array}$ & $\begin{array}{c}\text { Abundant 2.4/ } \\
\text { Infrequent } \\
\text { 64.3/ Absent } \\
33.3\end{array}$ \\
\hline & Russulaceae & Lactarius sp. 2 & 1 & 100 & 0 & 75.3 & $\begin{array}{c}\text { Contact 35.7/ } \\
\text { Medium smooth } \\
64.3\end{array}$ & $\begin{array}{c}\text { Absent 56.4/ } \\
\text { Infrequent } 48.7\end{array}$ & $\begin{array}{c}\text { Abundant 2.4/ } \\
\text { Infrequent } \\
\text { 64.3/ Absent } \\
33.3\end{array}$ \\
\hline & Paxillaceae & $\begin{array}{l}\text { Melanogaster } \\
\text { vittadinii }\end{array}$ & 1 & 100 & 100 & 85.5 & Long & Infrequent & Abundant \\
\hline & Sclerodermataceae & Pisolithus arhizus & 1 & 0 & 0 & 77 & NA & Infrequent & $\begin{array}{l}\text { Abundant 50/ } \\
\text { Infrequent } 50\end{array}$ \\
\hline & Sclerodermataceae & $\begin{array}{l}\text { Pisolithus } \\
\text { tinctorius* }\end{array}$ & 8 & 75 & 37.5 & 78.2 & NA & Infrequent & Infrequent \\
\hline & Russulaceae & $\begin{array}{l}\text { Russula } \\
\text { amoenolens* }\end{array}$ & 22 & 36.4 & 4.5 & 70.7 & $\begin{array}{l}\text { Short } 50 / \text { Medium } \\
\text { smooth } 50\end{array}$ & Infrequent & Infrequent \\
\hline & Russulaceae & Russula ilicis & 9 & 55.5 & 33.3 & 72.4 & $\begin{array}{c}\text { Contact } 44.2 \text { / } \\
\text { Short 13.0/ } \\
\text { Medium smooth } \\
33.8\end{array}$ & $\begin{array}{l}\text { Absent 5.2/ Infrequent } \\
\text { 84.4/ Abundant } 2.6\end{array}$ & $\begin{array}{c}\text { Infrequent } \\
\text { 44.2/ Absent } \\
55.8\end{array}$ \\
\hline & Russulaceae & Russula insignis* & 9 & 55.5 & 0 & 82.1 & Short & Infrequent & Absent \\
\hline & Russulaceae & $\begin{array}{l}\text { Russula } \\
\text { praetervisa }\end{array}$ & 33 & 44.8 & 17.2 & 72.9 & $\begin{array}{c}\text { Contact } 44.2 \text { / } \\
\text { Short 13.0/ } \\
\text { Medium smooth } \\
33.8\end{array}$ & $\begin{array}{c}\text { Absent 5.2/ Infrequent } \\
\text { 84.4/ Abundant } 2.6\end{array}$ & $\begin{array}{c}\text { Infrequent } \\
\text { 44.2/ Absent } \\
55.8\end{array}$ \\
\hline
\end{tabular}


Experimental observations

\begin{tabular}{|c|c|c|c|c|c|c|c|c|c|}
\hline Phylum & Family & Species & $n$ & $\begin{array}{l}\text { Emanating } \\
\text { hyphae }\end{array}$ & Rhizomorphs & Melanization & Exploration type & Emanating hyphae & $\begin{array}{l}\text { Rhizomorph } \\
\text { presence }\end{array}$ \\
\hline & Russulaceae & Russula sp. & 1 & 100 & 100 & 71.3 & $\begin{array}{c}\text { Contact } 44.2 \text { / } \\
\text { Short 13.0/ } \\
\text { Medium smooth } \\
33.8\end{array}$ & $\begin{array}{c}\text { Absent 5.2/ } \\
\text { Infrequent } 84.4 / \\
\text { Abundant } 2.6\end{array}$ & $\begin{array}{c}\text { Infrequent 44.2/ } \\
\text { Absent } 55.8\end{array}$ \\
\hline & Sclerodermataceae & Scleroderma сера & 4 & 75 & 0 & 71.9 & Long & Abundant & $\begin{array}{l}\text { Abundant } 75.0 / \\
\text { Infrequent } 25.0\end{array}$ \\
\hline & Sclerodermataceae & $\begin{array}{l}\text { Scleroderma } \\
\text { meridionale }\end{array}$ & 1 & 100 & 0 & 72.3 & Long & Abundant & $\begin{array}{l}\text { Abundant } 75.0 / \\
\text { Infrequent } 25.0\end{array}$ \\
\hline & Sclerodermataceae & Scleroderma sp. 1 & 1 & 100 & 0 & 69.7 & Long & Abundant & $\begin{array}{l}\text { Abundant } 75.0 / \\
\text { Infrequent } 25.0\end{array}$ \\
\hline & Sclerodermataceae & $\begin{array}{l}\text { Scleroderma } \\
\text { verrucosum }\end{array}$ & 17 & 94.1 & 41.2 & 73.3 & Long & Abundant & $\begin{array}{l}\text { Abundant } 75.0 / \\
\text { Infrequent } 25.0\end{array}$ \\
\hline & Thelephoraceae & $\begin{array}{l}\text { Thelephora } \\
\text { terrestris* }\end{array}$ & 61 & 88.5 & 11.5 & 69.8 & Medium smooth & Infrequent & $\begin{array}{l}\text { Abundant 50.0/ } \\
\text { Infrequent } 50.0\end{array}$ \\
\hline & Thelephoraceae & $\begin{array}{l}\text { Tomentella } \\
\text { castanea }\end{array}$ & 20 & 25 & 0 & 84.2 & NA & $\begin{array}{l}\text { Abundant } 33.3 \text { / } \\
\text { Infrequent } 66.6\end{array}$ & $\begin{array}{l}\text { Abundant 42.9/ } \\
\text { Infrequent } 57.1\end{array}$ \\
\hline & Thelephoraceae & $\begin{array}{l}\text { Tomentella } \\
\text { ferruginea }\end{array}$ & 8 & 62.5 & 62.5 & 86.8 & NA & $\begin{array}{l}\text { Abundant } 33.3 \text { / } \\
\text { Infrequent } 66.6\end{array}$ & $\begin{array}{l}\text { Abundant 42.9/ } \\
\text { Infrequent } 57.1\end{array}$ \\
\hline & Thelephoraceae & $\begin{array}{l}\text { Tomentella } \\
\text { lilacinogrisea }\end{array}$ & 3 & 100 & 66.7 & 83.9 & NA & $\begin{array}{l}\text { Abundant } 33.3 \text { / } \\
\text { Infrequent } 66.6\end{array}$ & $\begin{array}{l}\text { Abundant 42.9/ } \\
\text { Infrequent } 57.1\end{array}$ \\
\hline & Thelephoraceae & Tomentella sp. 1 & 1 & 100 & 0 & 86.3 & NA & $\begin{array}{l}\text { Abundant } 33.3 \text { / } \\
\text { Infrequent } 66.6\end{array}$ & $\begin{array}{l}\text { Abundant 42.9/ } \\
\text { Infrequent } 57.1\end{array}$ \\
\hline & Thelephoraceae & Tomentella sp. 10 & 1 & 100 & 100 & 94.7 & NA & $\begin{array}{l}\text { Abundant 33.3/ } \\
\text { Infrequent } 66.6\end{array}$ & $\begin{array}{l}\text { Abundant 42.9/ } \\
\text { Infrequent } 57.1\end{array}$ \\
\hline & Thelephoraceae & Tomentella sp. 2 & 7 & 57.1 & 14.3 & 83.9 & NA & $\begin{array}{l}\text { Abundant } 33.3 \text { / } \\
\text { Infrequent } 66.6\end{array}$ & $\begin{array}{l}\text { Abundant 42.9/ } \\
\text { Infrequent } 57.1\end{array}$ \\
\hline & Thelephoraceae & Tomentella sp. 3 & 1 & 0 & 0 & 94.3 & NA & $\begin{array}{l}\text { Abundant 33.3/ } \\
\text { Infrequent } 66.6\end{array}$ & $\begin{array}{l}\text { Abundant 42.9/ } \\
\text { Infrequent } 57.1\end{array}$ \\
\hline & Thelephoraceae & Tomentella sp. 4 & 4 & 100 & 0 & 92.9 & NA & $\begin{array}{l}\text { Abundant } 33.3 \text { / } \\
\text { Infrequent } 66.6\end{array}$ & $\begin{array}{l}\text { Abundant 42.9/ } \\
\text { Infrequent } 57.1\end{array}$ \\
\hline & Thelephoraceae & Tomentella sp. 5 & 10 & 100 & 30 & 82.4 & NA & $\begin{array}{l}\text { Abundant } 33.3 \text { / } \\
\text { Infrequent } 66.6\end{array}$ & $\begin{array}{l}\text { Abundant } 42.9 / \\
\text { Infrequent } 57.1\end{array}$ \\
\hline & Thelephoraceae & Tomentella sp. 6 & 16 & 32.5 & 6.3 & 79.7 & NA & $\begin{array}{l}\text { Abundant 33.3/ } \\
\text { Infrequent } 66.6\end{array}$ & $\begin{array}{l}\text { Abundant 42.9/ } \\
\text { Infrequent 57.1 }\end{array}$ \\
\hline
\end{tabular}


This is the accepted version of the published article available at https://doi.org/10.1016/j.soilbio.2018.03.021

Experimental observations

\begin{tabular}{|c|c|c|c|c|c|c|c|c|c|}
\hline Phylum & Family & Species & $\mathbf{n}$ & $\begin{array}{l}\text { Emanating } \\
\text { hyphae }\end{array}$ & Rhizomorphs & Melanization & Exploration type & Emanating hyphae & $\begin{array}{l}\text { Rhizomorph } \\
\text { presence }\end{array}$ \\
\hline & Thelephoraceae & Tomentella sp. 8 & 14 & 35.7 & 14.3 & 90.4 & NA & $\begin{array}{l}\text { Abundant } 33.3 \text { / } \\
\text { Infrequent } 66.6\end{array}$ & $\begin{array}{l}\text { Abundant } 42.9 \text { / } \\
\text { Infrequent } 57.1\end{array}$ \\
\hline & Thelephoraceae & Tomentella sp. 9 & 1 & 100 & 0 & 84 & NA & $\begin{array}{l}\text { Abundant } 33.3 \text { / } \\
\text { Infrequent } 66.6\end{array}$ & $\begin{array}{l}\text { Abundant } 42.9 \text { / } \\
\text { Infrequent } 57.1\end{array}$ \\
\hline
\end{tabular}




\section{Supporting Information}

Table S4 Forward selection of environmental variables for improving redundancy analysis of factors driving ectomycorrhizal community assembly in the Guadiamar river valley (SW Spain).

\section{Species-based redundancy model}

\begin{tabular}{lcccc}
\hline & & & & \\
Trace elements & Df & AIC & F & \multicolumn{2}{c}{$\operatorname{Pr}(>\mathrm{F})$} \\
\hline $\mathrm{S}$ & 1 & -3.6989 & 2.3380 & $0.005^{* *}$ \\
$\mathrm{Ni}$ & 1 & -4.3694 & 1.7278 & $0.005^{* *}$ \\
$\mathrm{Zn}$ & 1 & -3.8652 & 2.1855 & $0.005^{* *}$ \\
$\mathrm{Cu}$ & 1 & -3.2891 & 2.7170 & $0.005^{* *}$
\end{tabular}

\section{Soil Background Variables}

\begin{tabular}{lllll}
\hline Ca & 1 & -4.1287 & 2.9858 & $0.005 * *$ \\
Organic C & 1 & -4.6259 & 2.5075 & $0.005 * *$ \\
Total C & 1 & -4.0746 & 3.0383 & $0.005 * *$
\end{tabular}

CWM-based redundancy model

Trace elements

\begin{tabular}{lllll}
\hline Cu & 1 & 200.87 & 6.8637 & $0.010^{* *}$ \\
As & 1 & 201.55 & 7.6055 & $0.010^{* *}$ \\
Cd & 1 & 203.38 & 9.7030 & $0.005^{* *}$
\end{tabular}

\section{Soil Background Variables}

\begin{tabular}{lrrrl}
\hline CaCO3 & 1 & 199.88 & 6.0131 & $0.010^{* *}$ \\
Organic C & 1 & 202.55 & 8.8758 & $0.005^{* *}$ \\
Total C & 1 & 204.94 & 11.6547 & $0.005^{* *}$ \\
$\mathrm{P}$ & 1 & 196.62 & 2.8140 & 0.090. \\
\hline
\end{tabular}




\section{Supporting Information}

\section{Supporting Information Methods S1.}

\section{ECM fungal trait determinations}

The seven longest root fragments were selected from each root subsample. This made a total of 28 root fragments per tree. Root tips were selected randomly by choosing the extreme left of each root fragment. Each root tip was photographed in triplicates with a digital camera (Nikon DS-Fi1) fitted on a dissecting microscope. Two general pictures (25X magnification) on white and black background, and one detailed picture (100X magnification) on black background were taken, keeping light conditions at maximum and photograph exposition at $1 / 10$ s for the general pictures and $1 / 4 \mathrm{~s}$ for the detailed one (Fig. 1a-c). Three fungal traits - rhizomorphs, emanating hyphae and melanisation - were measured, as follows.

\section{Rhizomorphs}

The presence of rhizomorphs was recorded in the $25 \mathrm{X}$ magnified photographs. The presence of rhizomorphs was recorded for a root tip if a rhizomorph emerging from the cluster to which the selected root tip belongs was found (Fig. 1d-h). This procedure was chosen because rhizomorphs are less frequent than individual emanating hypha in a random root tip; however, individual root tips often are part of a bigger cluster of root tips of the same individual fungus.

\section{Emanating hyphae}

Emanating hyphae was determined at 100X magnification on black background photographs. The presence of emanating hyphae was recorded when hyphae appeared continuous and homogeneously distributed in the root tip surface (Fig. 1 I-n). However, when only individual, isolated, hyphae appeared, root tips were scored as having no emanating hyphae (Fig. $1 \mathrm{i}-\mathrm{k}$ ). 
d)
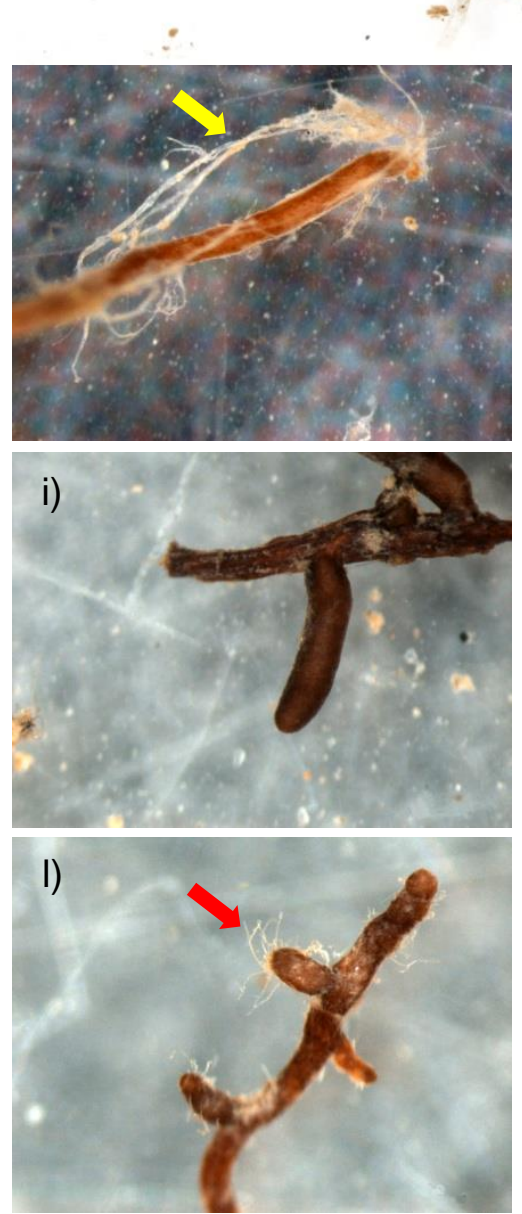

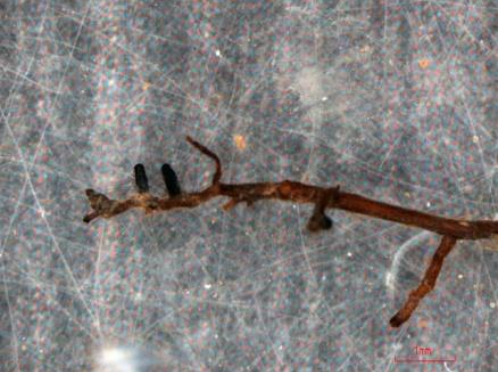

e)
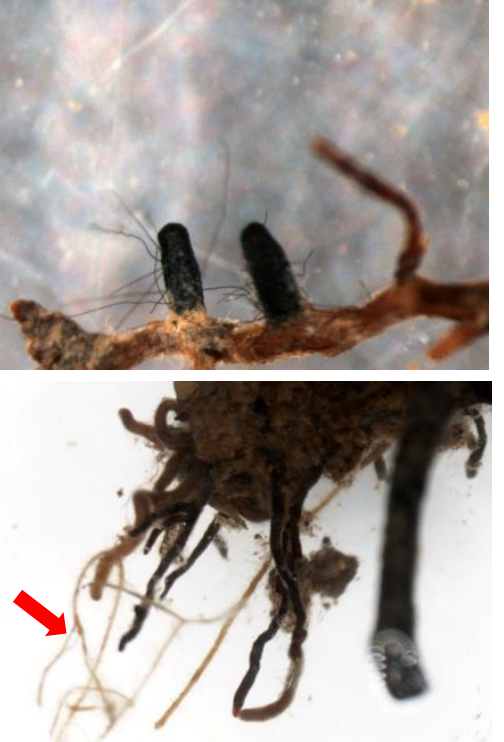
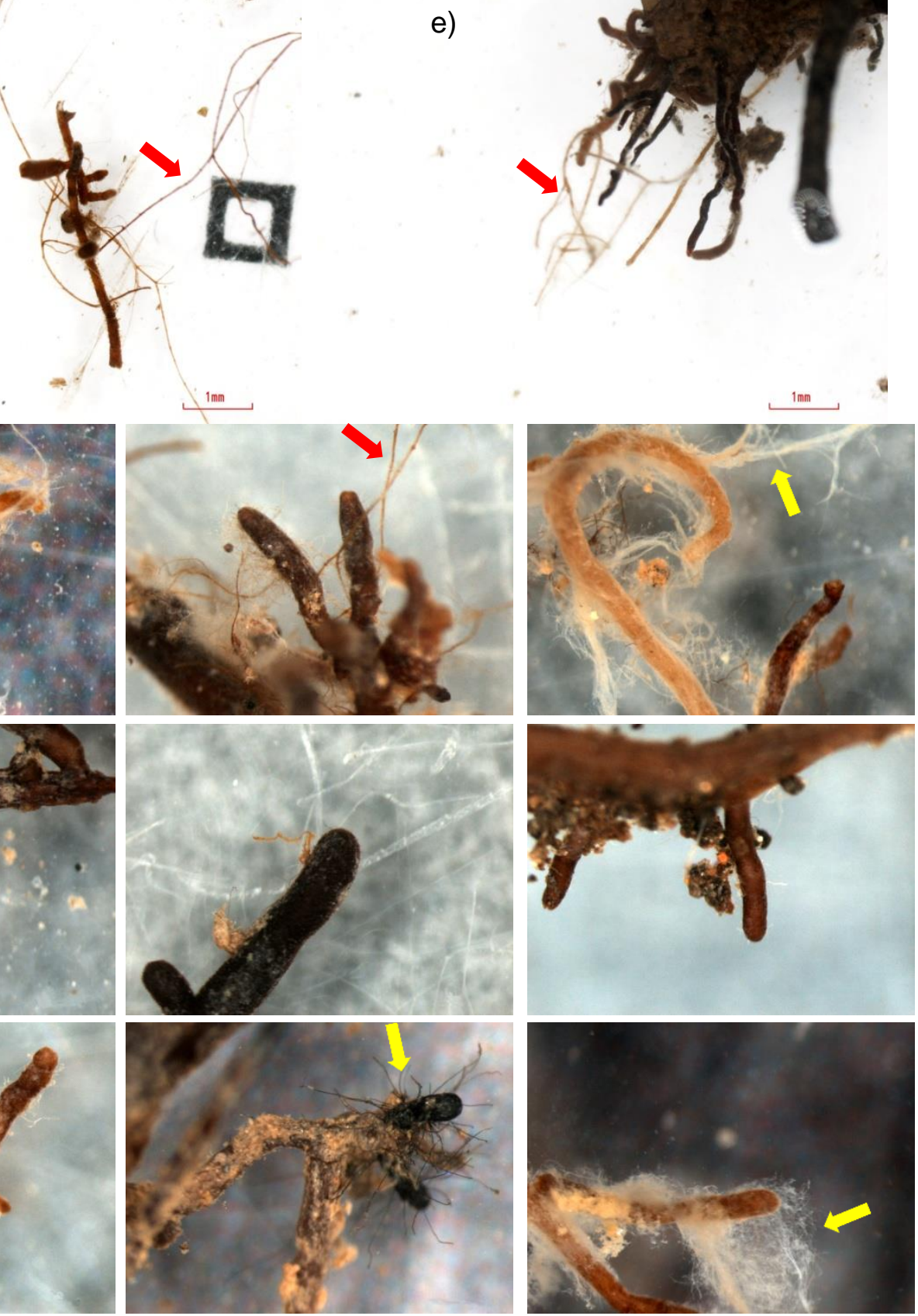

Fig. 1. Examples of photographs showing root tips with different fungal traits. a-c) Cenococcum geophylum root tips at $25 \mathrm{X}$ magnification $(\mathrm{a}, \mathrm{b})$ and $100 \mathrm{X}$ magnification $(\mathrm{c})$; $d-e)$ clusters of root tips with associated rhizomorphs (25X magnification); f-h) detailed of root tips showing rhizomorphs (100X magnification); i-k) root tips with no emanating hyphae (100X magnification); I-n) root tips showing different morphologies of emanating hyphae (100X magnification). The contrast of these pictures has been automatically improved to facilitate the visibility of fungal structures in this slide. 


\section{Melanisation}

The colour of root tips was assessed with the CMYB scale using ColorPick v. 3.0

(http://www.iconico.com/colorpic/). The CMYB scale decomposes colours in cyan, magenta, yellow and black components. Hence, the black colour content is annotated ranging from 0 , when completely white, to 1 , when completely black. Three locations per root tip were selected (as shown in Fig. 2) and the content in black annotated by clicking with the mouse. The final colour of a root tip was the average number of the three records in each root tip.

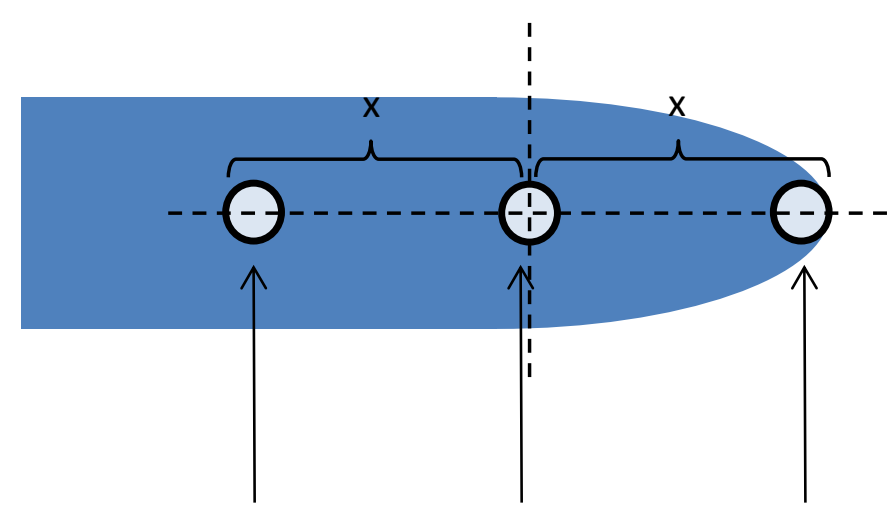

Record $1 \quad$ Record 2
Fig. 2. Schematic diagram of the location of the three points for colour recording in ECM root tips.

The darkness of the root tips, or the content in black colour, is directly related with the melanin content of fungi, in accordance with classical visual criteria used to differentiate between melanised and nonmelanised fungi (Fernández et al., 2016). Chand et al. (2014), for instance, classified fungi as white, mixed and black, and found that the melanin content was related to this classification. We applied our colorimetric approach to the photographs published by Fernandez \& Koide (2014) by recording the colour in three random locations of each photograph. We found a good correlation between black colour and melanin contents measured in that publication (Fig. 3).

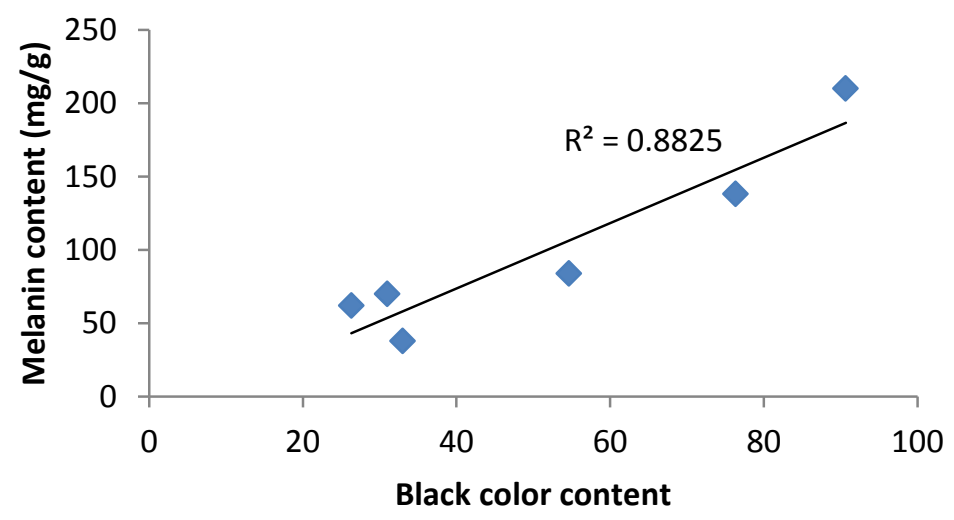

Fig. 3. Relationship between melanin content and black colour of fungal mycelia. The analysis corresponds to the photographs and melanin contents published by Fernandez \& Koide (2014). 


\section{Calculation of species trait values}

The frequency of emanating hyphae and rhizomorphs of each ectomycorrhizal fungal species was calculated as the proportion of root tips showing those traits in the whole study. Thus:

$$
\text { Trait value }=\frac{n_{i}}{N_{i}}
$$

where $n_{i}$ is the number of root tips with either emanating hyphae or rhizomorphs of the $i$-th species and $\mathrm{N}_{\mathrm{i}}$ is the total number of root tips belonging to $\mathrm{i}$-th species in the whole study. It resembles the fixed trait value described in Lepš et al. (2011) which is independent from the habitat conditions where the species is found.

Melanisation was calculated as the mean value of black colour content across all root tips belonging to a species. Thus:

$$
\text { Melanisation }=\frac{\sum_{j=1}^{N_{i}} \text { black }_{i j}}{N_{i}}
$$

where black $\mathrm{k}_{\mathrm{ij}}$ is the colour content of $\mathrm{i}$-th species in $\mathrm{j}$-th root tip and $\mathrm{N}_{\mathrm{i}}$ is the total number of root tips belonging to i-th species in the whole study. It is the fixed trait value described by Lepš et al. (2011).

\section{References}

Chand, R., Kumar, M., Kushwaha, C., Shah, K., Joshi, A.K. 2014. Role of melanin in release of extracellular enzymes and selection of aggressive isolates of Bipolaris sorokiniana in barley. Current Microbiology, 69, 202-211. doi: 10.1007/s00284-014-0559-y

Fernandez, C.W., Koide, R.T. 2014. Initial melanin and nitrogen concentrations control the decomposition of ectomycorrhizal fungal litter. Soil Biology and Biochemistry, 77, 150-157. doi:

10.1016/j.soilbio.2014.06.026

Fernandez, C.W., Langley, J.A., Chapman, S., McCormack, M.L., Koide, R.T. 2016. The decomposition of ectomycorrhizal fungal necromass. Soil Biology and Biochemistry, 93, 38-49. doi:

10.1016/j.soilbio.2015.10.017

Lepš, J., de Bello, F., Šmilauer, P., Doležal, J. 2011. Community trait response to environment: disentangling species turnover vs intraspecific trait variability effects. Ecography, 34, 856-863. doi: 10.1111/j.1600-0587.2010.06904.x 